\title{
New Diaptomidae records (Crustacea: Copepoda: Calanoida: Diaptomidae) in the Neotropical region
}

\author{
1 Minas Gerais State University. CEP 38200-000. Frutal, MG, Brazil. \\ 2 University of São Paulo, Zoology. CEP 05508-090. São Paulo, SP, Brazil \\ 3 Instituto Nacional de Pesquisas da Amazônia. CEP 69080-971, Manaus, AM, Brazil. \\ * Corresponding author. E-mail: dpreviattelli@gmail.com
}

Daniel Previattelli ${ }^{1 *}$, Gilmar Perbiche-Neves ${ }^{2}$ and Edinaldo Nelson dos Santos-Silva ${ }^{3}$

\begin{abstract}
TIn this study we present 208 new diaptomids records, including 36 species from 10 genera. They are the result of new samplings as well as of the revision of samples from previous surveys from various localities in the Neotropical Region. In an attempt to clear elucidate about the species ranges we gathered all biogeographically important data and present them here, with comments about the relevance of each record to the understanding of the distribution of the group.
\end{abstract}

\section{INTRODUCTION}

According to Dussart and Defaye (2002), despite the fact that genera are never cosmopolitan, members of Diaptomidae are almost anywhere in the world. On the other hand, the sister family Paradiaptomidae is limited to Africa (Ethiopian region) and to India, with the exception of four species (Santos-Silva 2008). The distribution of the Diaptomidae is also uneven, with one of the most diverse centers found in Neotropical freshwaters, possible due several evolutionary and dispersion trends along the periods (Boxshall and Jaume 2000; Suárez-Moráles et al. 2005).

Up to the last century Wright (1938b) and Brandorff (1976) recognized a poorly known area that extends from almostall the Amazon basin up to the Northwestern portion of the Paraná basin. On the other hand, the copepod fauna of the southeastern portion of the continent was much more studied (e.g. Sars 1901; van Douwe 1911; Brian 1926; Kiefer 1936; Ringuelet 1958; Ringuelet 1968), especially in ecological aspects (viz. Rocha and Matsumura-Tundisi 1976; Gloedem 1993; Reid and Pinto-Coelho 1994; MatsumuraTundisi and Silva 1999; Matsumura-Tundisi and Tundisi 2003; Casanova and Henry 2004; and Lansac-Tôha et al. 2004). As observed by Brandorff (1976) and MatsumuraTundisi (1986), this fact, lead Wright to presume that the most genera probably originated in the eastern part of Brazil and invaded the southern portion of the continent. This hypothesis was misled by the presence of species of Argyrodiaptomus in the southern region of the continent (e.g. Brandorff 1978; Brandorff et al. 1982; Robertson and Hardy 1984; Reid 1997; Espíndola et al. 2000, Previattelli and Santos-Silva 2007).

As further areas are being studied, the species richness of these organisms is proven higher in the Amazon region, with new species being described (Cicchino et al. 2001; Previattelli and Santos-Silva 2007). However, new species with very distinct morphology have been found in the middle section of the Paraná River basin (Paggi 2001, 2011; Perbiche-Neves et al. 2012), places that have already been intensively studied, as previously mentioned.

Phylogenetic and biogeographical patterns for most genera of the Neotropical Diaptomidae might indicate a close relationship between vicariant events and the evolutionary history of the group. In addition, a similar pattern is expressed by less inclusive monophyletic groups within each monophyletic genus. The more we have reliable records, better we will be able to understand such patterns. In this study we present new records of Diaptomidae for the Neotropical region, in order to provide a better understanding of the geographical distribution of these organisms, as well as to offer information for future biogeographic and evolutionary studies.

\section{MATERial AND Methods}

New records were obtained through samplings of various regions not previously accessed within the Neotropical region (sensu Wallace 1876 modified by Morrone and Marquez 2001). For that purpose, the authors collected samples by hauling a 56-micron-mesh plankton net, with aperture diameter of $25 \mathrm{~cm}$, through the limnetic portion of the water column. The material was concentrated and preserved in $4 \%$ formalin. Additionally, new records were made through the identification of material deposited at INPA-NIAR (Instituto Nacional de Pesquisas da Amazônia) and at MZUSP-ZMSP (Museu de Zoologia de São Paulo) by previous research projects that unintentionally left unsorted material from several localities. More details about other references and samples presented in this work can be found in Previattelli (2010) and Perbiche-Neves (2011).

For the biogeographic description the occurrences were plotted using the Google Earth software (Google Inc. 2012), based on the original information of the material collected. Doubtful records were not included in this work. All the geographical coordinates were then exported as a .kml file to the Quantum GIS (QGIS) software (Nanni et al. 2012). 17 maps were created by overlaying the plotted occurrences with the free vector files from Natural Earth (2012). Freshwater ecoregions biogeographical units were adopted in order to aggregate the occurrences and facilitate discussion of the relative importance of each (Abell et al, 2008). 
Specimens have been deposited in the invertebrate collection of INPA, MZUSP, and Natural History MuseumUK. General commentaries about the species are also given.

\section{RESULTS AND DISCUSSION}

In total, 208 new records were found (Figure 1). They include 36 species from 10 genera. From those, 16 species were exclusively from the Amazon basin, which includes the ecoregions: Amazonas Lowlands; Rio Negro; Madeira Brazilian Shield; Amazonas Estuary; and Tocantins ecoregions. Notodiaptomus cearensis (Wright 1936), N. coniferoides (Wright 1927) and Argyrodiaptomus azevedoi (Wright 1935) occur on both at the Northeastern Caatinga and the Coastal Drainages ecoregions of the Brazil and the Paraná basin, in a large area. Fifteen species were recorded from the Upper Paraná, and 5 species from the Lower Paraná. Notodiaptomus iheringi (Wright 1935) were recorded on the Northeastern Caatinga and on the Coastal Drainages, on the Northeastern Mata Atlantica, on the Iguassu and on the Upper Paraná ecoregions.

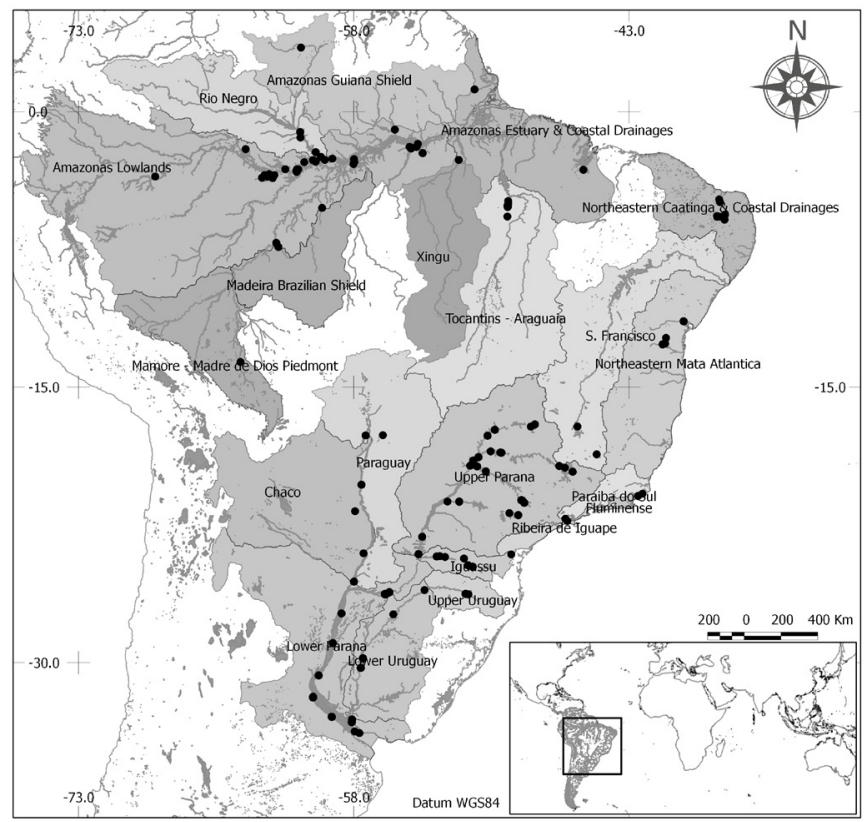

FIGURE 1. Location of all registered occurrences of Diaptomidae in Neotropical Region. Shaded areas indicate the freshwater ecoregions in which occurrences were found.

\section{Amazonas Lowlands/Rio Negro/Madeira/Mamoré/ Amazonas Estuary/Tocantins ecoregions}

Aspinus acicularis Brandorff 1973 has few records in the literature. In this study three new records are added, one taken from the vicinity of Manaus, one from the eastern region and one from the western portion of the Amazon basin (Figure 2). Frequently (and especially in the Tupé Lake), they are the sole calanoid species with a relatively high frequency and density (Previattelli et al. 2005). On the other hand they are rare in other Amazonian clear and white waters (water classification sensu Wallace 1853), making their occupation disrupted by such water bodies. That suggests a very well adapted but highly endemic species. Argyrodiaptomus robertsonae Dussart 1985 b seems to be less common, being found only in small numbers and in more complex and diverse environments (Figure 2). New records of Notodiaptomus simillimus
Cicchino Santos-Silva and Robertson 2001 were also found in the same region (Figure 2).

Notodiaptomus amazonicus (Wright, 1935) have three new records: one from Maracá Island, the first for the Amazonas and the Guiana Shield ecoregion, one from the Central Amazon (near Manaus) and one from the middle Solimões River (Figure 2), a region previously unexplored. Previous records of this species in the Paraná River basin are doubtful and they are, most likely, misidentifications. Comparing N. amazonicus from the Balbina Reservoir (Uatuma River, Amazonia, Brazil) with the samples from the Paraná River basin identified as N. amazonicus, notable differences could be found. Among them there were differences in the P5 shape and body length. Taking in account this fact, they will not be considered in this study until a taxonomic solution is proposed. Further studies on molecular analysis using COI gene may be necessary in order to clarify tangible differences between such groups Perbiche-Neves (pers. comm). Notodiaptomus deitersi (Poppe, 1891) was recorded in the Carajás region, enlarging the north occurrence limit of this species and including the oriental portion of the Amazon basin (Figure 3). Notodiaptomus brandorffi Reid, 1987 was found for the second time at a location near the type-locality (Figure 3), indicating a possible endemic species for the brackish waters that are found on that particular region. Notodiaptomus jatobensis (Wright, 1935) was found for the first time in the borders between the Xingu and the Amazonas Estuary and Coastal Drainages ecoregions (Figure 3).

Dactylodiaptomus pearsei (Wright, 1927) is widely distributed in the Amazon basin and it has also been registered in the Orinoco basin by Dussart (1984) and Cicchino (pers. comm). The most interesting new records are from the extreme eastern portion of the Amazon basin, at the Araguari River (Amapá State), which runs in parallel and to the left of the Amazon River, flowing directly into the ocean, on the Northernmost portion of the Amazonas

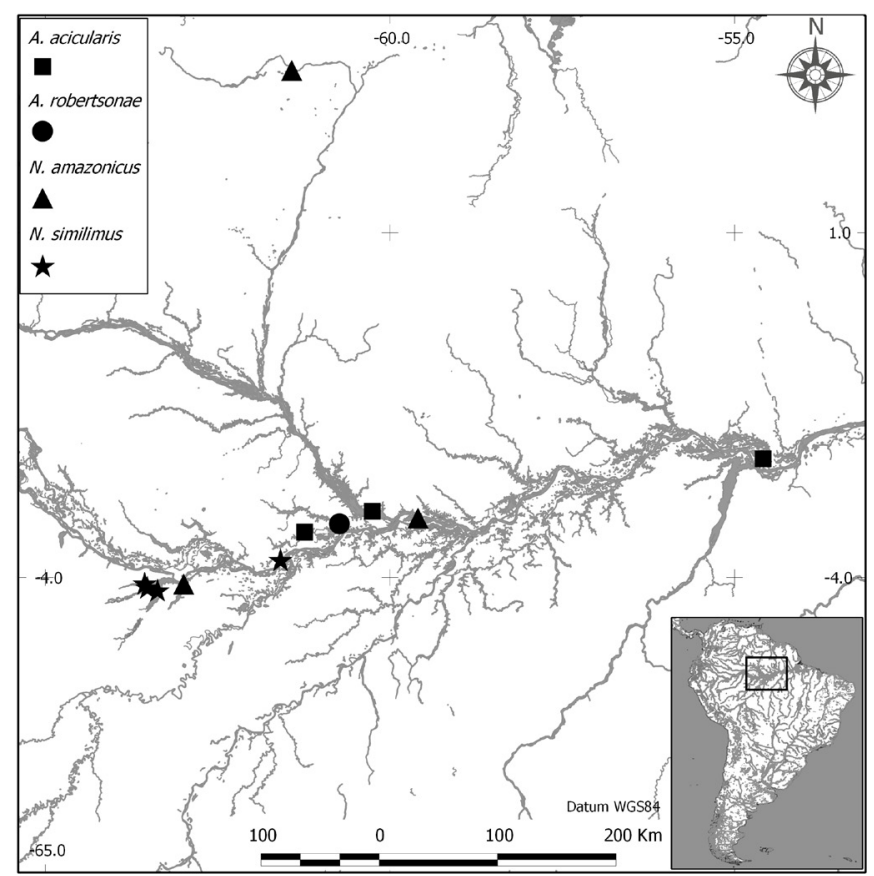

FigurE 2. New occurrences of Aspinus acicularis, Argyrodiaptomus robertsonae, Notodiaptomus amazonicus and $N$. similimus. 
Estuary and Coastal Drainages ecoregion (Figure 4). Argyrodiaptomus paggii Previattelli and Santos-Silva, 2007, receives the first record outside its type locality, expanding the distribution limits to the southwestern portion of the Amazon basin (Figure 4).

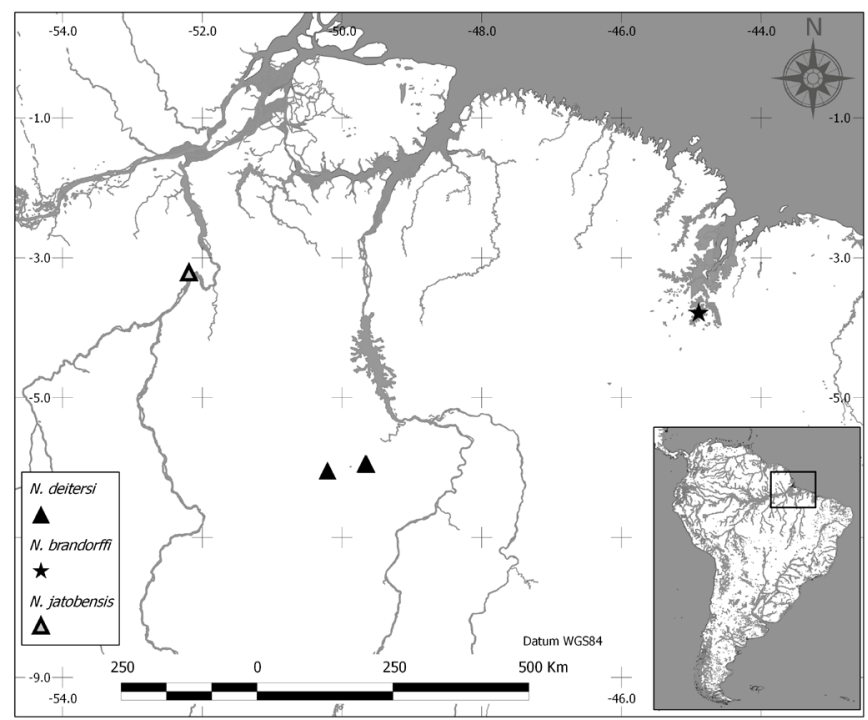

FiguRE 3. New occurrences of Notodiaptomus deitersi, N. brandorffi and N. jatobensis.

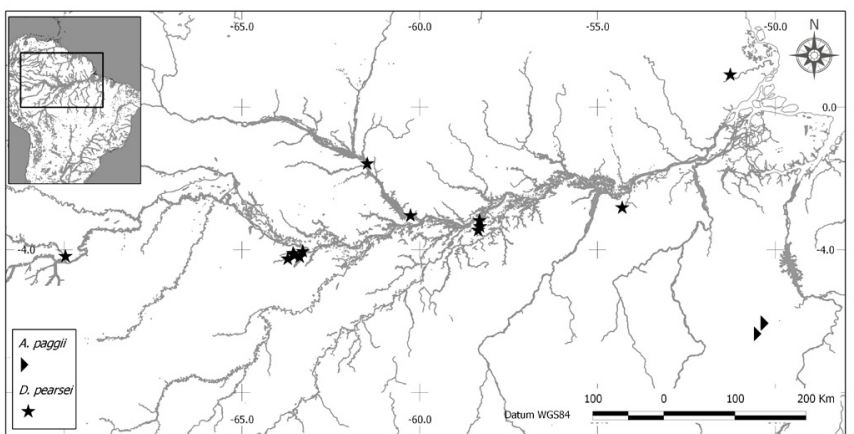

FigurE 4. New occurrences of Argyrodiaptomus paggii and Dactylodiaptomus pearsei.

“Diaptomus"s. l. ohlei Brandorff, 1978 is endemic to the Solimões/Amazon River, and apparently more connected to the Amazon River floodplain. New records were found along the Amazonas River main channel, from $50^{\circ}$ to $70^{\circ}$ (Figure 5).

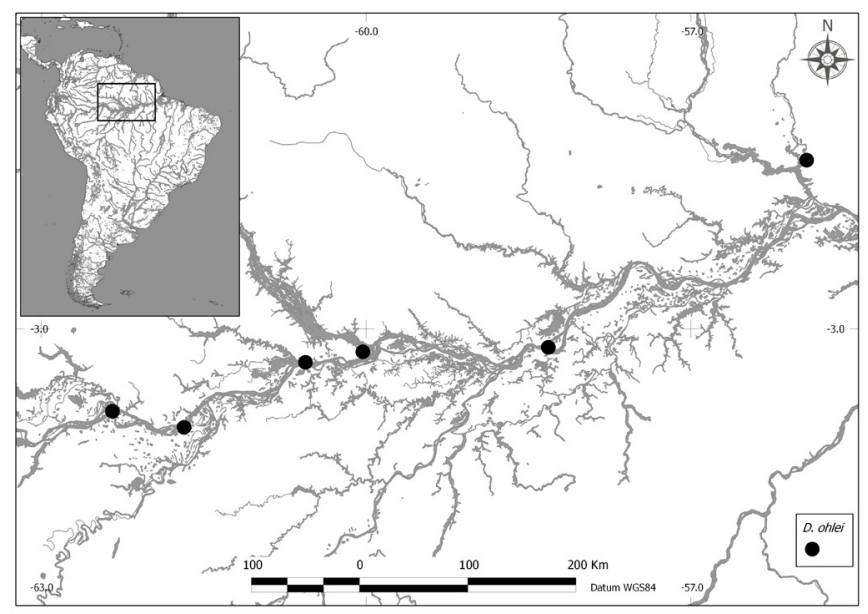

FigURE 5. New occurrences of "Diaptomus" s. l. ohlei.
Calodiaptomus merrillae (Wright, 1927) and Calodiaptomus perelegans (Wright, 1927) are typical from the southwestern boundaries of the Amazon, being also found at the western boundaries of the basin. They seem to be more related to white water rivers (water classification sensu Wallace 1853) and they appear in higher densities (Sendacz and Melo Costa 1991). The new records extend it to the central region of the Amazon (Figure 6), and thus lead to a wider distribution of the genus.

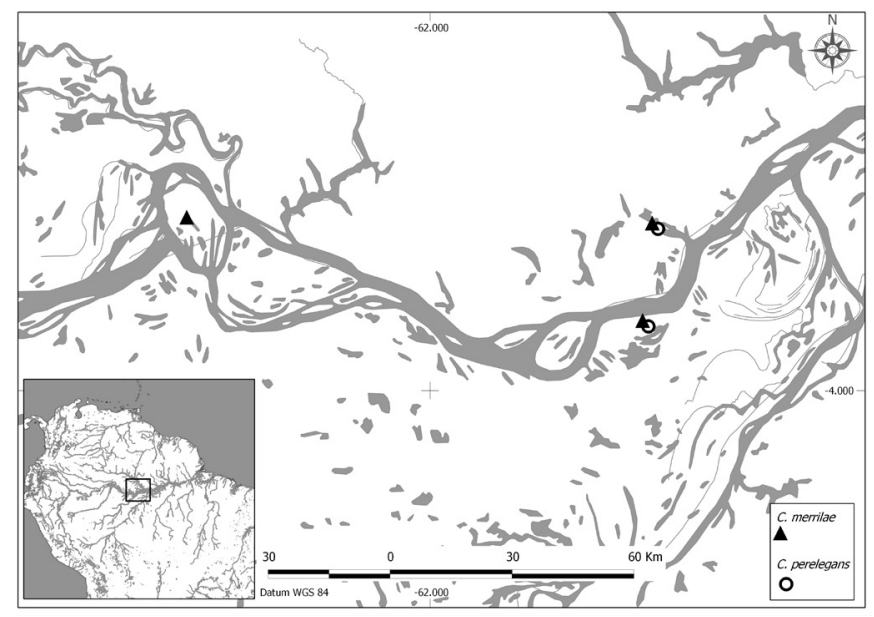

FIGURE 6. New occurrences of Calodiaptomus merrillae and C. perelegans.

Dasydiaptomus coronatus (Sars, 1901) is another very typical Amazonian species, but with occurrences reaching the São Francisco and the Paraná basins. All new occurrences are from the Amazon basin (Figure 7), mainly from the middle portion of the Negro River basin and near its confluence with the Solimões River.

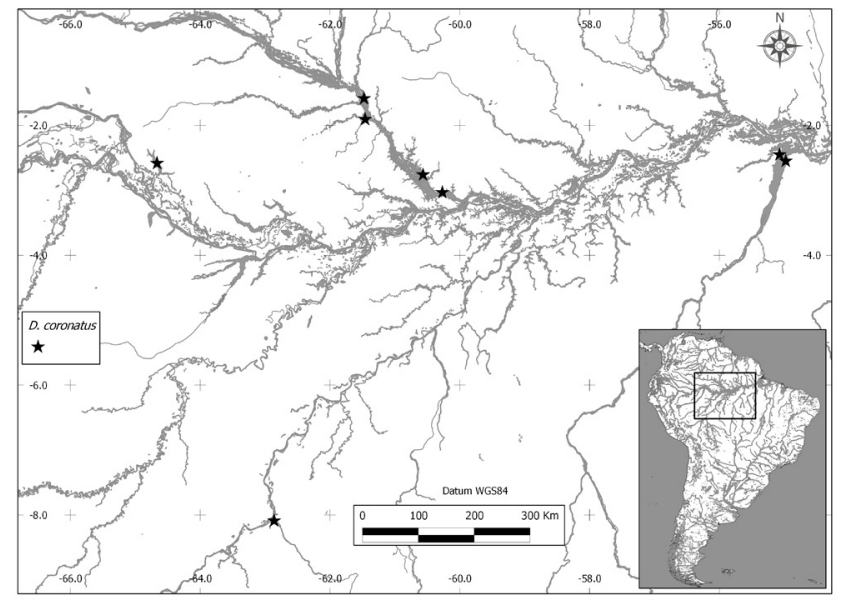

FIGURE 7. New occurrences of Dasydiaptomus coronatus.

Rhacodiaptomus genus is endemic to the Amazonic ecoregions. Rhacodiaptomus calamensis (Wright, 1927) was found at the mouth of Tapajós River. Rhacodiaptomus calatus Brandorff 1973 was recorded again in its type-locality (Calado Lake). Rhacodiaptomus insolitus (Wright, 1927) was registered in the Calama region (mouth of Machado River), southeastern Amazon basin. Rhacodiaptomus retroflexus Brandorff, 1973 was found together with $N$. amazonicus, $N$. coniferoides and $N$. simillimus at the Coari region (Figure 8). 


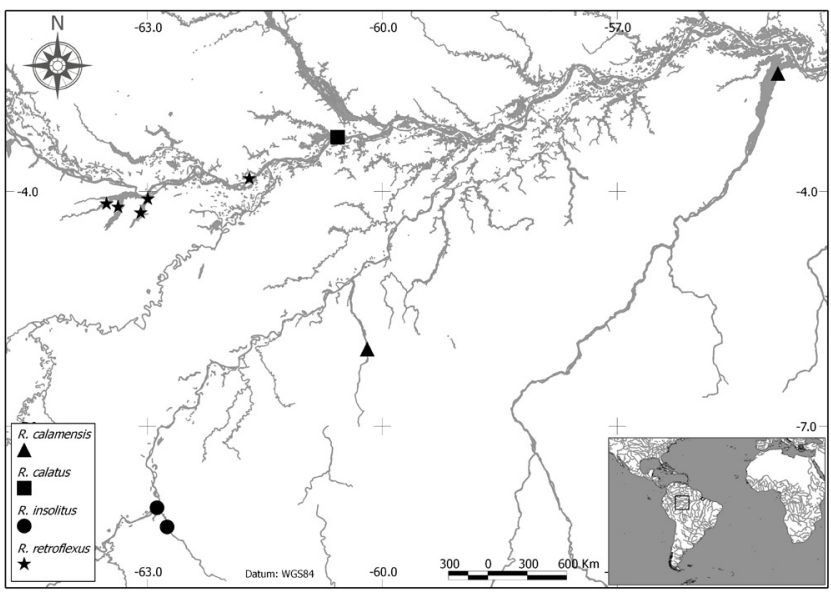

FIGURE 8. New occurrences of Rhacodiaptomus calamensis, $R$. calatus, $R$. insolitus and $R$. retroflexus.

\section{Atlantic Coast line/São Francisco/Paraiba do Sul/ Fluminense ecoregions}

Notodiaptomus cearensis Wright, 1936 was recorded for the first time in the state of Bahia (Brazil) (Figure 9). Even though there are few records, its occurrence is possibly more common and widespread. This species was found from the ecoregions of Alto Paraná River, up to the San Francisco, the Paraíba do Sul and the Fluminense ecoregions. These records indicate that this species is possibly distributed in warm climates, and it has limited distribution so far in the Tietê and Paraíba do Sul rivers, in almost all Brazilian Shield (eastern portion). There are also unpublished records of this species in the Billings dam in the city of São Paulo (Coelho-Botelho pers. comm.).

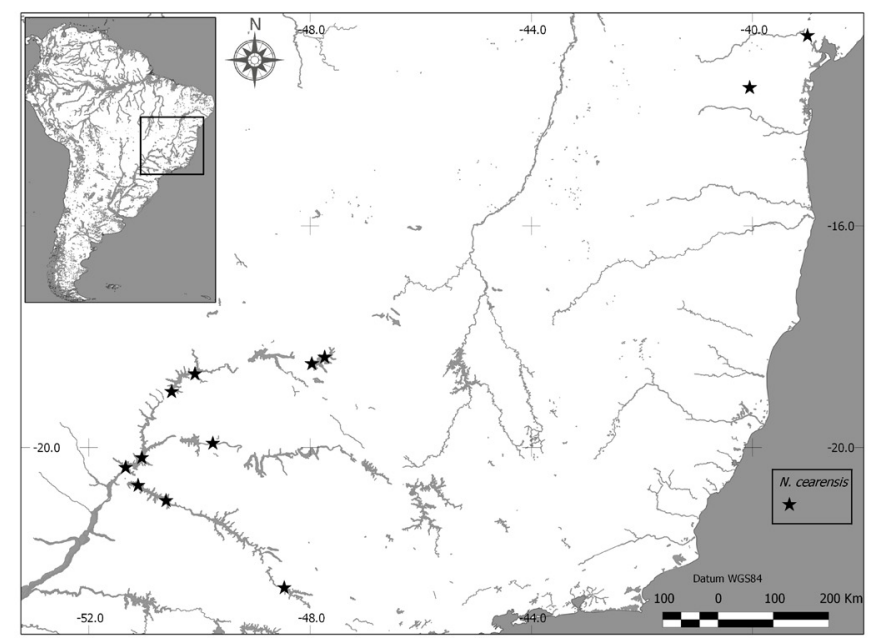

FIGURE 9. New occurrences of Notodiaptomus cearensis.

\section{Upper Paraná/ Lower Paraná/ Paraguay/ Chaco/ Ribeira do Iguape/ Iguassu/ Upper Uruguay/ Lower Uruguay}

Argyrodiaptomus denticulatus (Pesta, 1927) has a wide distribution in the Upper Paraná, Lower Paraná, Paraguay, Uruguay and Lower Chaco ecoregions. In the present work, we present a record for the Guaporé-Itenez ecoregions, which belongs to the Amazon basin, about 1,300 km north of previously known record (Figure 10). This record, in addition to other high portions of the Paraguay River, indicates that the species has great tolerance to water temperature variations. Santos-Silva (2008) points to a record of this species in southern Brazil, in Rio Grande do Sul State. Possibly this species is distributed along the Andes. This is one of the larger species among Diaptomidae.

Argyrodiaptomus falcifer (Daday, 1905) has been recorded in the middle and lower portions of the Paraná River (Paggi 2006). In this study we present another record for the same region (Figure 10). Paggi (2006) also stated that the species is a senior synonym of $A$. argentinus Wright, 1938.

Argyrodiaptomus furcatus (Sars, 1901) has been widely reported especially in the Upper Paraná ecoregion. In the present work we extend the distribution of this species to the Iguassu River and the beginning of the middle section of the Paraná River, the Yaciretá reservoir (Figure 10). Due to its similarity, this species can be mistaken for Argyrodiaptomus macrochaetus Brehm, 1937.

Notodiaptomus santafesinus Ringuelet and Martínez de Ferrato (1967) (Figure 10) is another typical species from the middle and lower Paraguay River. It has been commonly reordered in these regions (Frutos et al. 2006; José de Paggi and Paggi 2008).

Notodiaptomus spinuliferus (Dussart, 1985) has several records between latitudes 20 and $30^{\circ}$, being common in reservoirs, oxbow lakes and rivers, and in this work we present more records for the Upper Paraná, the Paraguay and Upper Uruguay ecoregions (Figure 10). Paggi (2001) made a taxonomic elucidation of the records made in Argentina, which were confused with other species such as N. dentatus Paggi (2001) and N. anisitsi (Lowndes, 1934). However, this species still needs to be substantially revised, since several problems were detected. As an example of such problems, we can mention the fact that there are two descriptions for this species (viz. Dussart 1985a; Dussart and Matsumura-Tundisi 1986). The first author mentions the second article that had not yet been published. He also describes the species with only a few illustrations. That led numerous other researchers to cite the second work as the authorship of the species. According to the international code of zoological nomenclature, the earliest description should be cited.

Pointing to a more serious problem, MatsumuraTundisi (2008) published a note correcting the 1986 publication (Dussart and Tundisi-Matsumura 1986). The author claims to have mistaken the illustrations of $N$. deitersi with $N$. spinuliferus, and indicates the illustrations

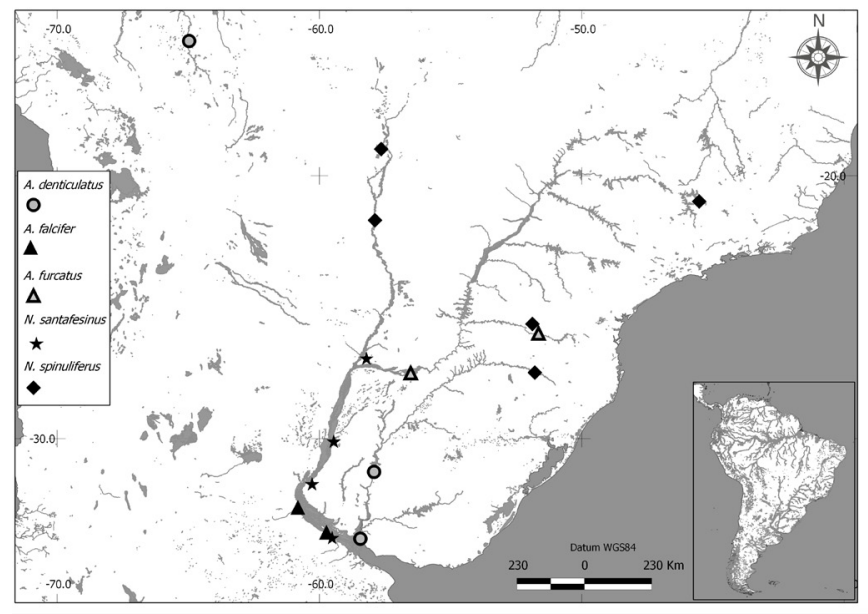

FiguRE 10. New occurrences of Argyrodiaptomus denticulatus, A. falcifer, A. furcatus, Notodiaptomus santafesinus and N. spinuliferus. 
of Matsumura-Tundisi (1986) as the one which is valid for this species. Thus a detailed review and redescription of the material deposited under that name in MZUSP (6971) becomes necessary, in order to verify the similarities with the drawings presented by Dussart (1985a), Dussart and Matsumura-Tundisi (1986), Matsumura-Tundisi (1986), Paggi (2001) and Matsumura-Tundisi (2008).

Notodiaptomus henseni Dahl, 1894 recorded in all upper Paraná Basin, being previously found only in the central parts of the Pantanal and the Amazon basins. In this study only recent records of Perbiche-Neves (2011) were added (Figure 11), but this species occurs specially in lentic water bodies such as reservoirs (e.g. Matsumura-Tundisi and Tundisi 2003; Nogueira et al. 2008) and marginal lakes (e.g. Casanova and Henry 2004; Lansac-Tôha et al. 2004, 2009), from north and northeast regions of Brazil (including Amazonian ecoregions) until the Iguassu ecoregion and the beginning of Middle Paraná River, at Yacireta Reservoir (Argentina/Paraguay). Matsumura-Tundisi et al. (2010) briefly described a new species ( $N$. oliveirai) found in Barra Bonita (Tietê River, São Paulo State, Brazil), which showed to be very similar to $N$. henseni, and with a wide distribution in this state. However, due to the similarities presented by the authors, this is possibly another synonym of $N$. henseni. Moreover, due to the lack of type material deposited in museum collections it should be considered a nomen nudum according to the International Commission on Zoological Nomenclature - ICZN. Population studies using detailed molecular analyzes, with the collection of material from the type locality (mouth of the Tocantins River, Pará State), are recommended in order to elucidate several questions regarding this species.

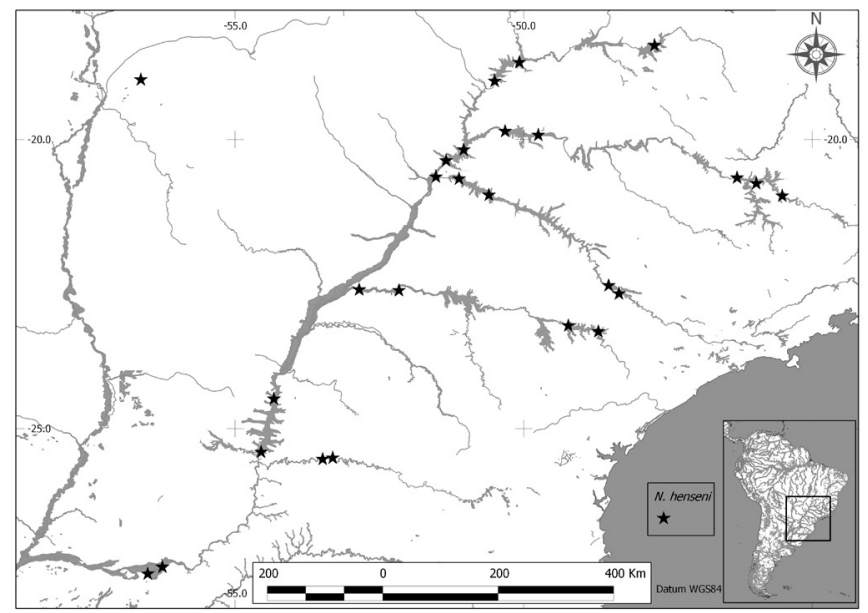

FIGURE 11. New occurrences of Notodiaptomus henseni.

"Diaptomus" s. l. azureus Reid, 1985 was recorded for the second time in the vicinity of Macaé city, Rio de Janeiro, indicating that it - together with D. s. l. fluminensis Reid 1985 - compose the endemic fauna of this region (Figure 12). Other species may be endemic to the coastal regions of South America, for example Notodiaptomus gibber (Poppe, 1889) in southern Brazil (Lower Paraná and Southeastern Mata Atlantica ecoregions). This trend may be a result of recent events of marine transgressions that occurred during the Pliocene and the Pleistocene. Possibly there are other species endemic to the coastal regions yet to be discovered.
Notodiaptomus iheringi (Wrigth, 1935) was found for the second time within the boundaries of the middle sector of the Paraná River basin (Figure 12), and together with $N$. henseni, $N$. cearensis, $N$. isabelae (Wrigth, 1936), $N$. conifer (Sars, 1901) and N. nordestinus (Wright, 1935), it has a wide distribution in the Brazilian Shield ecoregions. See commentaries for $N$. cearensis above.

Notodiaptomus coniferoides (Wright, 1927) (Figure 12 ) is a species with wide distribution in South America, ranging from the Amazon River to the mouth of the Paraná River. New records indicate a widespread occurrence in lotic systems because it had not been found in reservoirs sampled by Perbiche-Neves (2011). Nevertheless it is possible that this species occurs in lotic portions (not dammed), as in the floodplain of the upper Paraná River. This species was identified by Dussart (1984) for Venezuela, but later Cicchino et al. (2001) described a new species very similar to $N$. coniferoides, giving the name of N. simmilimus Cicchino, Santos-Silva and Robertson, 2001. Thus, there are possibly more than one species being identified as $N$. coniferoides throughout this large gradient distribution. Future studies may also elucidate this question.

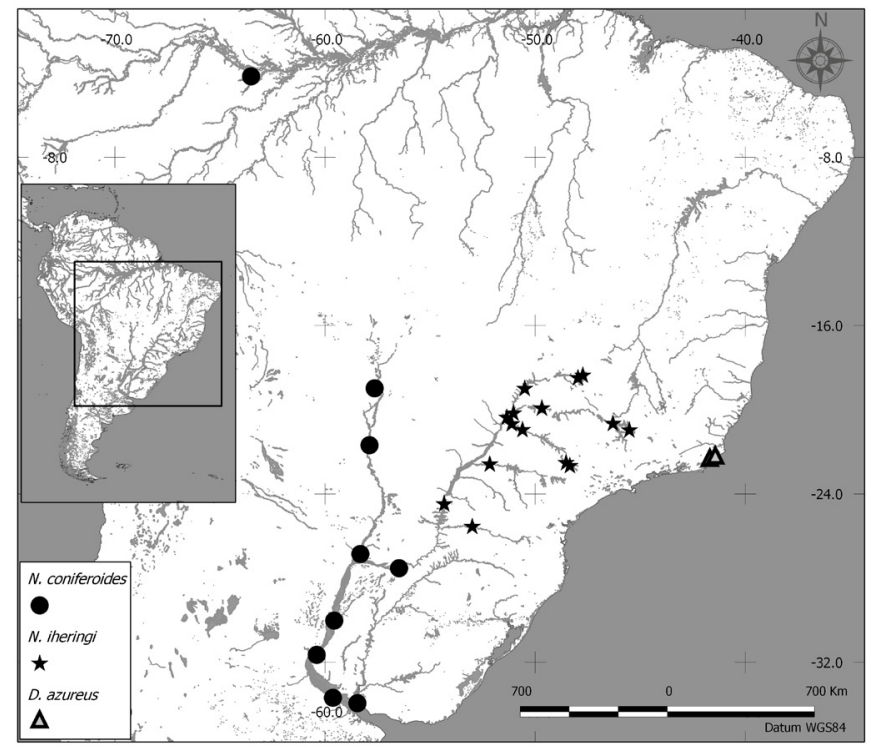

FIGURE 12. New occurrences of Notodiaptomus coniferoides, N. iheringi and "Diaptomus" s. l. azureus.

Argyrodiaptomus azevedoi is widely distributed from the northeastern to South reagion of Brazil (Figure 13). This species can be considered one of the largest (males body length with more than $1.7 \mathrm{~mm}$ ) among the Brazilian diaptomid fauna. They are usually found in small numbers in plankton samples, possibly due to its large size and ease of being preyed upon. That led some researchers to conclude that the species is disappearing, as well as others, but then again this explanation is currently unproven and it is possibly speculative.

Another record of Odontodiaptomus paulistanus (Wright, 1936) was made from the previously known region of Boracéia (Figure 13). Compared to other records, this species occurs widely in the southern region and in the Paraná State (South) in Brazil, presenting a distribution range of about $1,000 \mathrm{~km}$. Another species of this genus, O. thomseni (Brehm 1933), was recently 
rediscovered at Salto Grande Reservoir in the low Uruguay River (Perbiche-Neves et al. 2012), since 77 years had passed without any record. Moreover, the third species of this genus, O. michaelseni (Mrázek 1901), was not found since its original description.

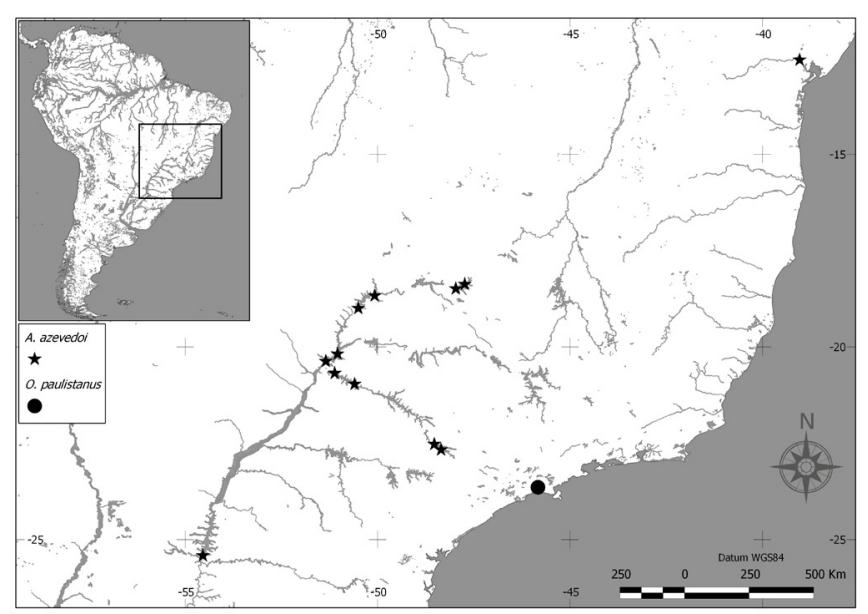

FIGURE 13. New occurrences of Argyrodiaptomus azevedoi and Odontodiaptomus paulistanus.

Notodiaptomus conifer (Sars, 1901), previously described for the northeastern region, was registered in several locations of the Prata River basin (Figure 14). Some researchers emphasize that this species was disappearing from reservoirs in the southeastern region of the country (Matsumura-Tundisi and Tundisi 2003; Nogueira et al. 2008), but this species was found precisely in these reservoirs and those with contrasting trophic states.

In addition, as other previously record, this species also occurred in a lotic portion of the lower Paraná River. This is an indication that specific limnological characteristics may not influence this species, or any replacement of the fauna, as previously thought. It merely highlights the concentration of these studies in reservoirs.

Similarly to other diaptomid species, these organisms are largely adapted to puddles. Small water bodies tend to have large oscillations of daily temperatures, as well as variations of other variables. Ecologic successions are complex and require long periods of time. Trends can be local or regional, and long, detailed spatial-temporal observations usually elucidate questions about the alleged disappearance or exchange of these species.

The search for reservoir water quality bioindicators sand its anthropic functionality has suppressed and masked the real dynamics and evolution of these organisms, a fact that should be strongly considered. Similar considerations can be made for $N$. iheringi, noticing that some very rare species have been recently rediscovered (e.g PerbicheNeves 2011).

Notodiaptomus dentatus Paggi, 2001 is a recently described species and it occurs at both Upper and Lower Paraná ecoregions. In the present study a new record was made at the Yaciretá reservoir, between Argentina and Paraguay, about $750 \mathrm{~km}$ north of the type locality (Figure 14). According to Paggi (2001), N. dentatus may occur together with $N$. anisitsi and $N$. spinuliferus, although the latter has not been included in this work because of its uncertain taxonomic status. Other species such as N. spiniger (Brian, 1926), N. isabelae, and some
Argyrodiaptomus also occur in the middle and lower portions of the Paraná River, and are part of the high richness of this region.

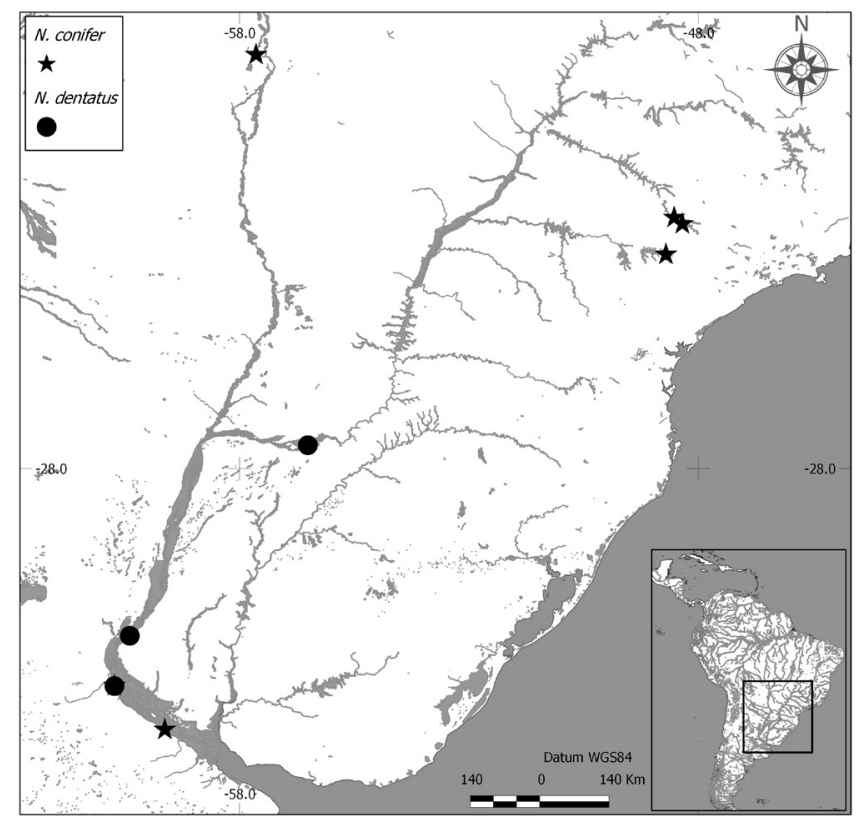

FIGURE 14. New occurrences of Notodiaptomus conifer and N. dentatus.

The new records of Notodiaptomus anisitsi Daday, 1905 confirm that this species is restricted to temperate or subtropical regions, occurring in southern Brazil, Argentina, Paraguay and Uruguay (Figure 15). It is a relatively easy species to distinguish due to the presence of the curved lateral spine at the right leg 5. Paggi (2001) has presented clear illustrations of this species, elucidating also doubts about the identification and confusion with other species, as well as showing their geographical distribution in Argentina. This species occurs in different types of environments such as rivers, lakes and lagoons, floodplains, reservoirs and water pools, becoming dominant at certain periods.

Notodiaptomus spiniger Brian, 1926 is also a species that occurs in temperate and subtropical South America, occurring in ponds, rivers, wetlands and reservoirs (Figure 15). Generally featuring large size (similar to Argyrodiaptomus species), $N$. spiniger demonstrates strong poecilandry effects, as described by Ringuelet and Martínez de Ferrato (1967). Their work also resulted in the synonym of Diaptomus toldti with $N$. spiniger. In this case, there is a smaller form of this species, which also features the less developed right antennule processes of males, in addition to smaller body size. Possibly it will be removed from the Notodiaptomus in the future, once it does not contain some of the diagnostic features of the genus.

Notodiaptomus isabelae (Wright, 1937) has a wide geographical distribution, ranging from the southeastern region of Brazil, the Doce River, up to the lower Paraná River in Argentina. However in this work we present only the new records from the middle portion of the Paraná River (Figure 16).

New records of Notodiaptomus carteri (Lowndes, 1934) are shown for the lower Paraná River, which occurs frequently. It also occurs in the middle section of this river; however records in Brazil and Paraguay are unknown 
(Figure 16). This may be an indication that this is a species restricted to the middle and lower sections of the Paraná River.

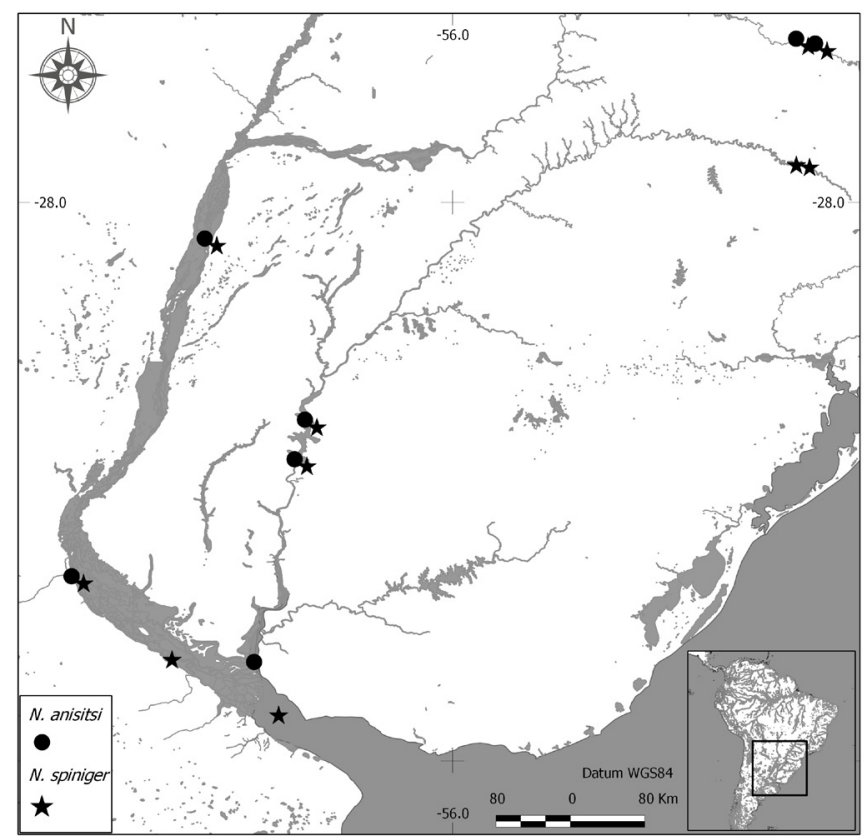

FIGURE 15. New occurrences of Notodiaptomus anisitsi and N. spiniger.

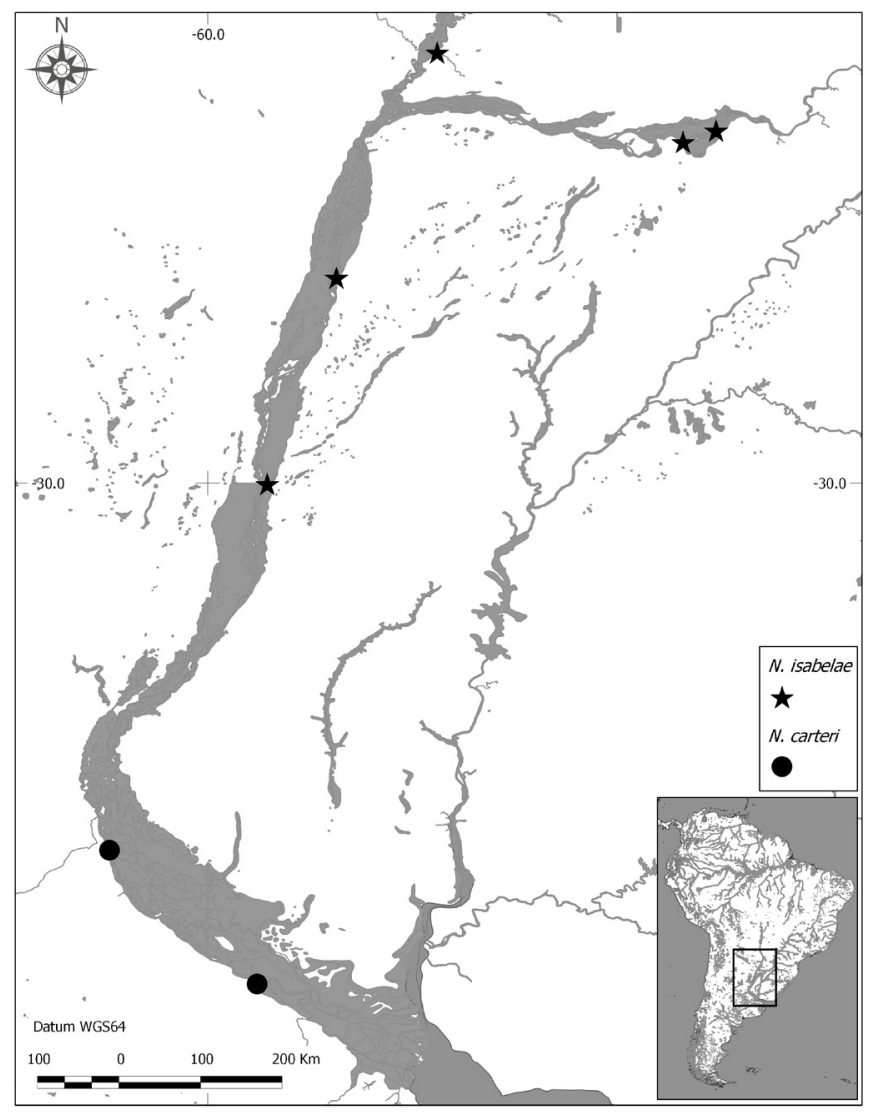

FIGURE 15. New occurrences of Notodiaptomus isabelae and N. carteri.

Notodiaptomus incompositus (Brian, 1926) is one of the most abundant species in the south of the basin (above the Iguassu River), especially in reservoirs and eutrophic water bodies. It is also dominant in lotic systems and mesotrophic reservoirs. This is possibly an opportunistic species, since it has a small body size. Perbiche-Neves (2011) found higher abundances in Iguassu (Foz do Areia
Reservoir), Uruguay (Machadinho Reservoir) and Mar del Plata rivers (Figure 17).

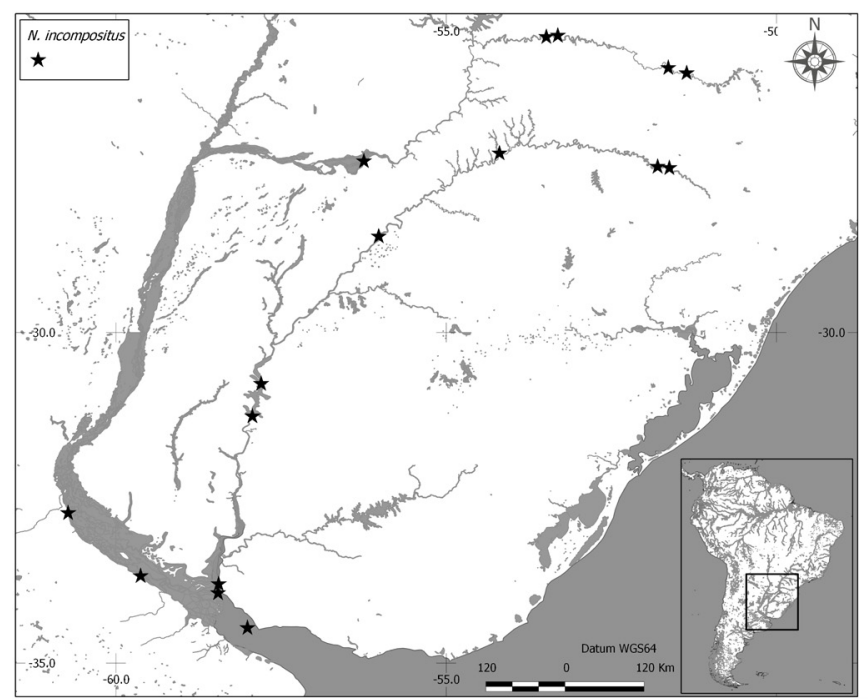

FIGURE 17. New occurrences of Notodiaptomus incompositus.

There are problems in the taxonomy of Neotropical Diaptomidae, most of them caused by mistakes in the descriptions. These mistakes led to many other errors as misidentifications by ecologists and confusion about the correct geographical distribution of some species. Few examples are Notodiaptomus spinuliferus, Notodiaptomus coniferoides, and recently for Notodiaptomus henseni, because of a possible synonymy with Notodiaptomus oliveirai Matsumura-Tundisi, Espindola, Tundisi, SouzaSoares, and Degani, 2010.

This study and others (e.g. Suárez-Morales et al. 2005) show that the genus Argyrodiaptomus is not restricted to the southern portions of South America, what is contrary to Brandorff (1976) and Matsumura-Tundisi (1986) findings. There are new records for this genus in the Amazonian ecoregions, including new species, indicating that this genus is more diverse than previously thought.

A more extensive view of the zoogeography of the freshwater Calanoida reveals that three families co-occur in the South American continent. The Centropagidae Giesbrecht 1892 ranges from Patagonia to the Andes, with few records in other regions: first, two species were found in Rio Grande do Sul State, Brazil (Gloeden 1994, 1997) and more recently Perbiche-Neves pers. comm. found Boeckella in Santa Catarina State, Brazil. Pseudodiaptomidae occurs in shallow coastal waters (Walter 1989), with only four native species in one genus (Pseudodiaptomus) and four species (Santos-Silva 2008). Diaptomidae are distributed in the remaining parts of the subcontinent, except in high altitudes and latitudes. Between the areas of exclusive distribution of Centropagidae and Diaptomidae, there is an overlapping zone ranging from the delta of the Paraná River to The Northern Patagonia region (Wright 1938b; Brandorff 1976; and Bănărescu 1990).

According to Wright (1938b), the South America occupation history by the Diaptomidae agrees with the Archamazonia and Archiplata theory (von Ihering 1900), where portions of the continent were separated by an epicontinental sea during the Tertiary. The Diaptomidae would have, originally, an Archamazonia distribution, while 
the Centropagidae occupied the Andes/Patagonia region, corresponding to the original Archiplata distribution.

Several South American diaptomid species are rare, as supported by this study. They have few records and are almost always found in low abundances. Examples of that would be "Diaptomus" s. l. azureus, "Diaptomus" s. l. fluminensis, Odontodiaptomus thomseni, Argyrodiaptomus bergi (Richard 1897), and Idiodiaptomus dussarti Paggi 2011, among others.

However, while the results indicate that these species occur in a particular environment, the pattern might be only occasional. That happens because plankton samplings are limited both spatially and temporally. Probably the sampling rarefaction curve is the problem behind this, and a more careful design is paramount in order to define truly representative diversity surveys.

Thus, it is expected that as more studies are performed, especially in regions that have gaps, and even in supposedly well-studied regions, more records of missing or rare species will occur. Studies are needed in the Midwest and northern portions of the Continent, where there are possibly several new species, as well as extended occurrences of others.

Considering the boundaries where other groups occur, we can hitherto notice blank areas. Large portions of the Neotropical region are still poorly sampled, for example the Brazilian states of Mato Grosso, Tocantins, Acre, and other countries such as Bolivia, Peru, Ecuador and the Andean Mountain Basins. Further studies are needed in order to determine the extent of the influence and the level of endemism of the Neotropical and Neartic regions, as well as the sub-areas of the South American continent. Spatial units must be reconsidered using, for example, optimization criteria to determine the areas of endemism as shown by Szumik and Goloboff (2004) in order to avoid the problem of using unreliable biogeographic units.

Moreover, some of the regions with few records were already surveyed to be used in the Environmental Impact Assessment (EIA). This is a requirement of the Brazilian federal legislation regarding any new enterprise or impoundment. When this involves water bodies such as river damming or effluent disposal, the study must include the aquatic community. Nevertheless the identification of the sampled specimens is usually not reliable and rarely reaches the species level. This low resolution hinders the utilization of the EIA for solving distribution questions and even greatly compromise the purpose of the study itself, once the detection of possible aquatic community alterations (e.g. as a consequence of the anthropic activity) cannot be made. This situation makes it even more important the deposition of identified material in national or international public museums or collections, such that the material can be available for future reference, confirmation and comparison.

In this study part of the material came from unsorted samples left by previous research projects. Future research projects should consider devoting more time and effort to the sample processing and identification in order to avoid leaving in overdue important information.

ACKNOWLEDGMENTS: The authors would like to thank to FAPESP (process 2008/02015-7, 2009/00014-6, 2011/18358-3) for financial support (to
G.P.-N); CNPq (process 141702/2006-0) for financial support to D.P.).

\section{Literature Cited}

Abell, R., M.L. Thieme, C. Revenga, M. Bryer, M. Kottelat, N. Bogutskaya, B. Coad, N. Mandrak, S. Contreras Balderas, W. Bussing, M.L.J. Stiassny, P. Skelton, G.R. Allen, P.Unmack, A. Naseka, R. Ng, N. Sindorf, J. Robertson, E. Armijo, J.V. Higgins, T.J. Heibel, E. Wikramanayake, D. Olson, H.L. López, R.E. Reis, J.G. Lundberg, M.H. Sabaj Pérez, and P. Petry. 2008. Freshwater Ecoregions of the World: A New Map of Biogeographic Units for Freshwater Biodiversity Conservation. BioScience 58(5): 403-414.

Bănărescu, P. 1990. Zoogeography of freshwaters. Vol.1. Wiesbaden: AulaVerslag. 511 p.

Boxshall, G.A. and D. Jaume. 2000. Making waves: the repeated colonization of fresh water by copepod crustaceans. Advanced Ecological Research 31: 61-79.

Brandorff, G.O. 1973. Neue Frielebende Calanoide Copepoden (Crustacea) au dem Amazonasgebiet. Amazoniana 4 (2): 205-218.

Brandorff, G.O. 1976. The geographic distribution of the Diaptomidae in South America (Crustacea, Copepoda). Revista Brasileira de Biologia, 36(3): 613627.

Brandorff, G.O., 1978. Ein neuer Diaptomid (Crustacea, Copepoda) "Diaptomus" ohlei aus den brasilianischen Amazonasgebiet. Archiv für Hydrobiologie 82: 295-299.

Brandorff, G.O., W. Koste and N.N. Smirnov. 1982. The composition and structure of Rotiferan and Crustacean Communities of the Lower Rio Nhamundá, Amazonas, Brasil. Studies on Neotropical Fauna and Environment 17: 69-121.

Brehm, V. 1933a. Diaptomus thomseni nov. spec., ein merkwürdiger neuer Diaptomus aus Uruguay. Zoologischer Anzeiger 104: 221-224.

Brehm, V. 1933b. Argyrodiaptomus granulosus nov. spec., ein neuer Diaptomus aus Uruguai. Zoologischer Anzeiger 103: 283-287.

Brian, A. 1926. Di alcuni copepodi d acqua dolce dell'Argentina. Memorie della Societa Entomologica Italiana 4: 177-200.

Casanova, S.M.C. and H. Henry. 2004. Longitudinal distribution of Copepoda populations in the transition zone of Paranápanema river and Jurumirim reservoir (São Paulo, Brazil) and interchange with two lateral lakes. Brazilian Journal of Biolgy 64(1): 11-26.

Cicchino, G.N., E.N. Santos-Silva and B. Robertson. 2001. A new species of Notodiaptomus Kiefer, 1936 (Copepoda, Diaptomidae) from the Amazon and Orinoco River basins. Hydrobiologia 156: 25-31.

von Daday, E. 1905. Untersuchungen über die Sübwassermikrofauna Paraguays. Zoologica 44: 1-349.

van Douwe, C. 1911. NeueSüsswassercopepoden aus Brasilien. Zoologischer Anzeiger 37: 161-163.

Dussart, B.H., 1984. Some Crustacea Copepoda from Venezuela. Hydrobiologia 113: 25-67.

Dussart, B.H. 1985a. Sur quelques copépodes d'Amérique du Sud, V. Diaptomidae. Archiv für Hydrobiologie 103(2): 201-215.

Dussart, B.H. 1985b. Another new diaptomid (Crustacea, Copepoda) from the Brazilian Amazon. Amazoniana 11(2): 275-280.

Dussart, B.H. and D. Defaye. 2002. World Directory of Crustacea Copepoda of Inland Waters. I - Calaniformes. Leyden: Backhuys Publ. 276 p.

Dussart, B.H. and T. Matsumura-Tundisi. 1986. "Nouvelles Espècies Calanoides du Brèsil." Revista Brasileira de Biologia 46(1): 249-255.

Espíndola, E.L.G., T. Matsumura-Tundisi, A.C. Rietzler and J.G. Tundisi. 2000. Spatial heterogeneity of the Tucuruí Reservoir (state of Pará, Amazonia, Brasil) and the distribution of zooplanktonic species. Revista Brasileira de Biologia 60: 179-194.

Frutos. S.M., A.S.G. Poi de Neiff and J.J. Neiff. 2006. Zooplankton of the Paraguay River: a comparison between sections and hydrological phasess. Annales de limnologie - International Journal of Limnology 42: 277-288.

Giesbrecht, W. 1892. Systematik und faunistik der pelagischen Copepoden des Golfes von Neapel und der angrenzenden Meeresabschnitte. Fauna und Flora des Golfes von Neapel und angrenzenden Meeresabschnitte 19: 1-831.

Gloedem, I.M. 1993. Ocorrência de Argyrodiaptomus denticulatus Pesta, 1927 (Crustacea, Copepoda) na lagoa dos patos, Rio Grande do Sul, Brasil. Nauplius 1: 91-92.

Gloeden, I.M. 1994. Ocorrência de Boeckella bergi Richard,1897 (Copepoda, Calanoida) na Lagoa Mirim, Rio Grande do Sul, Brasil. Nauplius 2: 123-124.

Gloeden, I.M. 1997. First record of Pseudoboeckella poppei Mrázek, 1901 (Copepoda, Calanoida, Centropagidae) in Brasil. Nauplius 4: 173-174.

Google Inc., 2012. Google Earth (version 7.0.2.8415). Available at http://earth. google.com/. Captured on 1 Febuary 2013.

José de Paggi, S.B. and J.C. Paggi. 2008. Hydrological Connectivity as a Shaping Force in the Zooplankton Community of Two Lakes in the Paraná River Floodplain. Internat. Revista de Hydrobiologia 93: 659-678.

Kiefer, F. 1936. Über die systematik der südamerikanischen diaptomiden (Crustacea Copepoda). Zoologischer Anzeige 116(7/8): 194-200.

Lansac-Tôha, F.A., C. Boneker and L.F.M. Velho. 2004. Composition, species richness and abundance of the zooplankton community; p. 145-190 In S.M. Thomaz, A.A. Agostinho and N.S. Hahn (ed.). Physical aspects, Ecology 
and Conservation. Leiden: Backhuys Publishers.

Lansac-Tôha, F.A., C.C. Bonecker, L.F.M. Velho, N.R. Simões, J.D. Dias, G.M. Alves and E.M. Takahashi, 2009. Biodiversity of zooplankton communities in the Upper Paraná River floodplain: interannual variation from long-term studies. Brazilian Journal of Biology 69(2): 539-549.

Lowndes, A.G. 1934. Results of an expedition to Brasil and Paraguay in 1926-7 supported by the trustees of the Percy Sladen Memorial Fund and the Executive Committee of the Carnegie Trust for Scotland. Copepoda. Journal of the Linnean Society. Zoology 39(263): 83-131.

Martin, J.W. and M.S. Laverack. 1992. On the Distribution of the Crustacean Dorsal Organ. Acta Zoologica 73(5): 357-368.

Matsumura-Tundisi, T. 1986. Latitudinal Distribution of Calanoida Copepods in Freshwater aquatic Systems of Brasil. Revista Brasileira de Biologia 46(3): 527-553.

Matsumura-Tundisi, T. 2008. Rectification of description of Notodiaptomus spinuliferus Dussart and Matsumura-Tundisi, 1986. Brazilian Journal of Biology 68(3): 683-684.

Matsumura-Tundisi, T. and W.M. Silva. 1999. Crustáceos copépodos planctônicos; p. 1-176 In C.A. Jolly, C.E.M. Bicudox (ed.). Biodiversidade do Estado de São Paulo-Invertebrados de Água Doce. Volume IV. São Paulo: FAPESP.

Matsumura-Tundisi, T. and J.G. Tundisi. 2003. Clanoida (Copepoda) species composition changes in the reservoirs of São Paulo state (Brazil) in the last twenty years. Hydrobiologia 504: 215-222.

Matsumura-Tundisi, T., E.L.G. Espindola, J.G. Tundisi, F. Souza-Soares and R.M. Degani. 2010. A new species of Notodiaptomus Kiefer (Crustacea, Copepoda, Calanoida, Diaptomidae) from Brazil. Brazilian Journal of Biology. 70(3): 867-870.

Morrone, J.J. and J. Márquez. 2001. Halffter's Mexican Transition Zone, beetle generalized tracks, and geographical homology. Journal of Biogeography 28: 635-650.

Mrázek, A., 1901. Süsswasser-Copepoden. Hamburg: L. Friederichsen \& Company. 29 p.

Nanni, A.S., L. Descovi Filho, M.A. Virtuoso, D. Montenegro; G. Willrich, P.H. Machado, R. Sperb, G.S. Dantas and Y. Calazans. 2012. Quantum GIS Geographic Information System. Open Source Geospatial Foundation Project. Accessible at http://qgis.osgeo.org. Accessed on Febuary 2013.

Natural Earth. 2012. Free vector and raster map data. Accessible at http://naturalearthdata.com. Captured on Febuary 2013.

Nogueira, M.G., P.C. Reis-Oliveira and Y.T. Britto. 2008. Zooplankton assemblages (Copepoda and Cladocera) in a cascade of reservoirs of a large tropical river (SE Brazil). Limnetica 27(1): 151-170.

Paggi, J.C. 2001. Clarification of the taxonomic status of Notodiaptomus anisitsi (Daday, 1905) and related species, with description of a new species from Argentina (Crustacea: Copepoda: Diaptomidae). Hydrobiologia 453/454: 549-564.

Paggi, J.C. 2006. Redescription and re-evaluation of the taxonomic status of the Neotropical copepod Diaptomus falcifer Daday, 1905 (Calanoida: Diaptomidae). Studies on Neotropical Fauna and Environment 41(1): 67-78.

Paggi, J.C. 2011. A new species of the rare genus Idiodiaptomus Kiefer, 1936 (Copepoda, Calanoida, Diaptomidae) from northeastern Argentina. Crustaceana Monographs 16: 1570-7024

Perbiche-Neves, G. 2011. Copépodes planctônicos (Crustacea, Calanoida e Cyclopoida) em reservatórios e trechos lóticos da bacia do rio da Prata (Brasil, Paraguai, Argentina e Uruguai): taxonomia, distribuição geográfica e alguns atributos ecológicos. PhD thesis. Botucatu: State University of São Paulo - UNESP. 207p.

Perbiche-Neves, G., G.A. Boxshall, C.E.F. Rocha and M.G. Nogueira. 2012. Rediscovered after 77 years: Odontodiaptomus thomseni - a rare species of calanoid (Crustacea: Copepoda) from South America. Zoologia 29(2): 172-179.

Pesta, 0. 1927. Ein Beitrag zur Kenntnis der Copepodofauna von Argentinen. Zoologischer Anzeiger 73(3/4): 67-80.

Poppe, S.A., 1891. Ein neuer Diaptomus aus Brasilien. Zoologischer Anzeiger 14: 248-250.

Previattelli, D. 2010. Phylogeny and biogeography of the neotropical Diaptominae. PhD thesis. Manaus: Federal University of Amazonas INPA. 238 p.

Previattelli, D. and E.N. Santos-Silva. 2005. Distribuição vertical do zooplâncton e sua relação com as variáveis ambientais; p. 109-121 In E.N. Santos-Silva, F.M. Aprile, V.V. Scudeller, and S. Melo, (ed.). Biotupé: meio físico, diversidade biológica e cultural. Volume 1. Manaus: INPA.

Previattelli, D. and E.N. Santos-Silva. 2007. A new Argyrodiaptomus (Copepoda: Calanoida: Diaptomidae) from the southwestern Brazilian Amazon. Zootaxa 1518: 1-29.
Reid, J.W. 1985. Calanoid copepods (Diaptomidae) from coastal lakes, State of Rio de Janeiro, Brasil. Proceedings of the Biological Society of Washington 98: 574-590.

Reid, J.W. 1987. Scolodiaptomus, a new genus proposed for Diaptomus (sensu lato) corderoi Wright, and description of Notodiaptomus brandorffi, new species (Copepoda: Calanoida), from Brasil. Journal of Crustacean Biology 72: 364-379.

Reid, J.W. 1997. Argyrodiaptomus nhumirim, a new species, and Austrinodiaptomus kleerekoperi, a new genus and species, with redescription of Argyrodiaptomus macrochaetus Brehm, new rank, from Brazil (Crustacea: Copepoda: Diaptomidae). Proceedings of the Biological Society of Washington 110(4): 581-600.

Reid, J.W. and R.M. Pinto-Coelho. 1994. Planktonic copepoda of Furnas Reservoir: Initial survey of species (1993) and review of literature; $p$. 93-114 In R.M. Pinto-Coelho, A. Giani and E. von Sperling (ed.) Ecology and human impact on lakes and reservoirs in Minas Gerais with special reference to future development and management strategies. Belo Horizonte: SEGRAC.

Richard, J. 1897. Sur quelques entomostracés d'eau douce des environs de Buenos Aires. Anales del Museo Nacional de Buenos Aires 5: 321 332.

Ringuelet, R.A. 1958. Los crustáceos copépodos de las águas continentales de la República Argentina: Sinopsis sistemática. Contribuciones Científicas. Serie Zoologia, Facultad de Ciencias Exactas e Naturales. Universidad de Buenos Aires 1(2): 35-126.

Ringuelet, R.A. 1968. Biogéographie des Copépodes d'eau douce de l'Argentine. Biologie de l'Amérique Australe 6: 261-267.

Ringuelet, R.A. and A. Martínez de Ferrato. 1967. Notas sobre diaptómidos argentinos (Crustacea, Copepoda). Physis 26(73): 411-420.

Robertson, B.A. and E.R. Hardy. 1984. Zooplankton of Amazonian lakes and rivers; p. 337-352 In H. Sioli, (ed.). The Amazon: Limnology and Landscape Ecology of a Mighty Tropical River and Its Basin. Monographiae Biologicae. Dordrecht: Dr. W. Junk Publishers.

Rocha, O. and T. Matsumura-Tundisi. 1976. Atlas do zooplâncton (Represa do Broa, São Carlos). Vol. 1 - Copepoda. São Carlos: Universidade de São Carlos. 65 p.

Santos-Silva, E.N. 2008. Calanoid of the families Diaptomidae, Pseudodiaptomidae, and Centropagidae from Brasil. Biologia Geral e Experimental 8(1): 3-67.

Sars, G.O. 1901. Contribution to the knowledge of the freshwater Entomostraca of South America, as shown by artificial hatching from dried material. Part II. Copepoda Calanoida. Bergen: Bergen Museum. 145-171 p.

Sendacz, S. and S.S. Melo Costa. 1991. Caracterização do zooplâncton do rio Acre e lagos Lua Nova, Novo Andirá e Amapá (Amazônia, Brasil). Revista Brasileira de Biologia 51: 463-470.

Suárez-Morales, E., J.W. Reid and M. Elías-Gutiérrez. 2005. Diversity and Distributional Patterns of Neotropical Freshwater Copepods (Calanoida: Diaptomidae). Internationale Revue der Hydrobiolgie 90(1): 71-83.

Szumik C. and P. Goloboff. 2004. Areas of endemism: An improved optimality criterion. Systematic Biology 53: 968-977.

Wallace, A.R., 1853. A Narrative of Travels on the Amazon and Rio Negro. London: Reeves. 624 p.

Wallace, A.R. 1876. The Geographical Distribution of Animals: with a study of the relations of living and extinct faunas as elucidating the past changes of the earth's surface. 2 Vol. London: Macmillan. 1110 p.

Walter, T.C. 1989. Review of the New World species of Pseudodiaptomus (Copepoda: Calanoida), with a key to the species. Bulletin of Marine Science 45: 590-628.

Wright, S. 1927. A revision of the South American Species of Diaptomus. Transactions of American Microscopical Society 2: 73-115.

Wright, S. 1935. Tree New Species of Diaptomus from Northeast Brazil. Anais da Academia Brasileira de Ciências 7(3): 215-233.

Wright, S. 1936. Preliminary report on six new species of Diaptomus from Brasil. Anais da Academia Brasileira de Ciências 7: 79-85.

Wright, S. 1938a. A review of the Diaptomus bergi group, with description of two new species. Transactions of the American Microscopical Society 57(3): 297-315.

Wright, S. 1938b. Distribuição geographica das espécies de Diaptomus na América do Sul. Livro Jubilar do Professor Travassos 3: 561-566.

RECEIVED: February 2013

ACCEPTED: June 2013

Published online: August 2013

EDITORIAL RESPONSIBILITY: Luis Ernesto Arruda Bezerra 
Appendix. Aspinus, Argyrodiaptomus, Calodiaptomus species and their respective latitude and longitude.

\begin{tabular}{|c|c|c|c|}
\hline & SPECIES & LONG./ LAT. & DESCRIPTION \\
\hline 1 & A. acicularis & $-54.58248 /-2.275950$ & Jacaré Lake, Tapajós River, Santarém, Pará, Brazil, 11.XI.2006. Col. Calixto, L.S.F \& Pimpão, D.M. INPA 1595 \\
\hline 2 & & $-60.25755 /-3.039597$ & Cemitério Stream, Tupé Lake, Manaus, Amazonas State, Brazil. 15.II.2003, 18h00. \\
\hline 3 & & $-61.23781 /-3.341822$ & Cabaliana Lake, Amazonas State, Brazil. \\
\hline 4 & A. azevedoi & $-39.03136 /-12.55246$ & Pedra do Cavalo Reservoir, Paraguaçu River, Bahia State, Brazil, 05.V.2012. Col. Serafim Jr., M. \\
\hline 5 & & $-47.96795 /-18.48873$ & $\begin{array}{l}\text { Emborcação Reservoir, Parnaíba River, Upper Paraná River Basin, Goiás State, Brazil. II.2010. Col. Perbiche- } \\
\text { Neves, G. }\end{array}$ \\
\hline 6 & & $-47.73531 /-18.37265$ & $\begin{array}{l}\text { Emborcação Reservoir, Parnaíba River, Upper Paraná River Basin, Goiás State, Brazil. II.2010. Col. Perbiche- } \\
\text { Neves, G. }\end{array}$ \\
\hline 7 & & $-50.07767 /-18.67152$ & $\begin{array}{l}\text { São Simão Reservoir, Parnaíba River, Upper Paraná River Basin, Minas Gerais State, Brazil. II.2010. Col. Perbiche- } \\
\text { Neves, G. }\end{array}$ \\
\hline 8 & & $-50.50230 /-18.99794$ & $\begin{array}{l}\text { São Simão Reservoir, Parnaíba River, Upper Paraná River Basin, Minas Gerais State, Brazil. II.2010. Col. Perbiche- } \\
\text { Neves, G. }\end{array}$ \\
\hline 9 & & $-51.04175 /-20.18164$ & Ilha Solteira Reservoir, Upper Paraná River, São Paulo State, Brazil. II.2010. Col. Perbiche-Neves, G. \\
\hline 10 & & $-51.34685 /-20.37346$ & Ilha Solteira Reservoir, Upper Paraná River, São Paulo, Brazil \\
\hline 11 & & $-51.11557 /-20.68234$ & Três Irmãos Reservoir, Tietê River, Upper Paraná River, São Paulo State, Brazil. II.2010. Col. Perbiche-Neves, G. \\
\hline 12 & & $-50.59821 /-20.96608$ & Três Irmaos Reservoir, Tietê River, Upper Paraná River, São Paulo State, Brazil. II.2010. Col. Perbiche-Neves, G. \\
\hline 13 & & $-48.35109 /-22.66912$ & Barra Bonita Reservoir, Tietê River, Upper Paraná River, São Paulo State, Brazil. II.2010. Col. Perbiche-Neves, G. \\
\hline 14 & & $-48.52649 /-22.52496$ & Barra Bonita Reservoir, Tietê River, Upper Paraná River, São Paulo State, Brazil. II.2010. Col. Perbiche-Neves, G. \\
\hline 15 & & $-54.54183 /-25.41656$ & Itaipu Reservoir, Upper Paraná River, Paraguay/Brazil. I.2010. Col. Perbiche-Neves, G. \\
\hline 16 & A. denticulatus & $-64.96812 /-14.86842$ & $\begin{array}{l}\text { Beni River, Bolívia, Ponto } 1 \text { coleta do "Report of a Preliminary Lymnological Study of Beni Waters" (not } \\
\text { published, 27.IX.1975, Col. Brandorff, G.O.) }\end{array}$ \\
\hline 17 & & $-57.91717 /-31.26636$ & Salto Grande Reservoir, Low Uruguay River, Uruguay. I.2010. Col. Perbiche-Neves, G. \\
\hline 18 & & $-58.43902 /-33.81054$ & Lower Uruguay River, Uruguay. II.2010. Col. Perbiche-Neves, G. \\
\hline 19 & A. falcifer & $-60.71220 /-32.73118$ & Lower Paraná River, Santa Fé Province, Argentina. II.2010. Col. Perbiche-Neves, G. \\
\hline 20 & & $-59.62211 /-33.67577$ & Lower Paraná River, Santa Fé Province, Argentina. I.2010. Col. Perbiche-Neves, G. \\
\hline 21 & A. furcatus & $-51.64911 /-25.99739$ & $\begin{array}{l}\text { Foz do Areia Reservoir, Iguassu River, Upper Paraná River Basin, Paraná State, Brazil. II.2010. Col. Perbiche- } \\
\text { Neves, G. }\end{array}$ \\
\hline 22 & & $-56.52123 /-27.50686$ & Yaciretá Reservoir, Middle Paraná River, Argentina/Paraguay \\
\hline 23 & A. paggii & $-50.20832 /-6.043371$ & N3 Lake, Serra Norte, Carajás, Pará State, Brazil. INPA 1578 \\
\hline 24 & & $-50.39278 /-6.356484$ & S11D-C Lake, Serra Sul, Carajás, Pará State, Brazil. INPA 1572 \\
\hline 25 & & $-50.19097 /-6.058536$ & N4A Lake, Serra Norte, Carajás, Pará State, Brazil. INPA 1585 \\
\hline 26 & A. robertsonae & $-60,73083 /-3.220877$ & Manacapuru Lake, Amazonas State, Brazil. \\
\hline 27 & C. merrilae & $-61.67994 /-3.220877$ & Ananá Lake, Amazonas State, Brazil. Gasoduto Coari-Manaus Project \\
\hline 28 & & $-62.34830 /-3.754888$ & Araçá Lake, Amazonas State, Brazil. Gasoduto Coari-Manaus Project \\
\hline 29 & & $-61.66583 /-3.763255$ & Anorí Lake, Amazonas State, Brazil. Gasoduto Coari-Manaus Project \\
\hline 30 & C. perelegans & $-61.67994 /-3.906056$ & Ananá Lake, Amazonas State, Brazil. Gasoduto Coari-Manaus Project \\
\hline 31 & & $-61.66583 /-3.763255$ & Anorí Lake, Amazonas State, Brazil. Gasoduto Coari-Manaus Project \\
\hline 32 & D. pearsei & $-61.47444 /-1.58640$ & Jauaperi River, Amazonas State, Brazil. 11.III.2005. INPA 1645 \\
\hline 33 & & $-58.30077 /-3.353059$ & $\begin{array}{l}\text { Itapaíuna Lake, Itacoatiara, Amazonas River, Amazonas State, Brazil 11.VII.2005, 12h10. Col.: Calixto, L.S.F. INPA } \\
1590\end{array}$ \\
\hline 34 & & $-58.31799 /-3.18197$ & Sucuriju Lake, Itacoatiara, Amazonas River, Amazonas State, Brazil 11.VII.2005, 11h14. Col.: Calixto, L.S.F. \\
\hline 35 & & $-51.26338 / 0.91024$ & Samuel Reservoir, Ferreira Gomes, Amapá State, Brazil, 18.VIII.2009. Col. Previattelli, D. \\
\hline 36 & & $-60.25774 /-3.03972$ & Cemitério Stream, Tupé Lake, RDS Tupé, Manaus, Amazonas State, Brazil, 09.III.2003. col. Previattelli, D. \\
\hline 37 & & $-69.96224 /-4.186033$ & Yahuarcaca Lake, Leticia, Colombia, I.2009. Col. Riaño, N.J.A. \\
\hline 38 & & $-58.35448 /-3.453847$ & $\begin{array}{l}\text { Araçazinho Lake, Itacoatiara, Amazonas River, Amazonas State, Brazil. 13.VII.2005, 12h20. Col.: Calixto, L.S.F. } \\
\text { INPA } 1653\end{array}$ \\
\hline 39 & & $-63.28736 /-4.046547$ & Coarí Lake, Coarí, Amazonas State, Brazil. VI. 2008. Col. Darwich, A. J. Gasoduto Coari-Manaus Project \\
\hline 40 & & $-63.52083 /-4.15875$ & $\begin{array}{l}\text { Urucu Ria Lake, Coarí, Amazonas State, Brazil. Sample LURC. VI. 2008. Col. Darwich, A. J. Gasoduto Coari-Manaus } \\
\text { Project }\end{array}$ \\
\hline 41 & & $-63.71097 /-4.254527$ & $\begin{array}{l}\text { Urucu River, Coarí, Amazonas State, Brazil. Sample URC .7. VI. 2008, Col. Darwich, A. J. Gasoduto Coari-Manaus } \\
\text { Project }\end{array}$ \\
\hline 42 & & $-63.37296 /-4.200152$ & $\begin{array}{l}\text { Coari Ria Lake, Coarí, Amazonas State, Brazil. Sample LRCO. VI. 2008. Col. Darwich, A. J. Gasoduto Coari-Manaus } \\
\text { Project }\end{array}$ \\
\hline 43 & & $-63.56004 /-4.100075$ & $\begin{array}{l}\text { Aruã Ria Lake, Coarí, Amazonas State, Brazil sample LRARVI. 2008. Col. Darwich, A. J. Gasoduto Coari-Manaus } \\
\text { Project }\end{array}$ \\
\hline 44 & & $-51.26338 / 0.9102440$ & Samuel Reservoir, Ferreira Gomes, Amapá State, Brazil, 18.VIII.2009. Col. Previattelli, D. \\
\hline 45 & D. coronatus & $-54.97655 /-2.549960$ & Tapajós River, Alter do Chão, West of Santarém, Pará State, Brazil. 20.IX.1991. Col. E. N. Santos-Silva \\
\hline 46 & & $-61.47444 /-1.586408$ & Jauaperi River , Amazonas State, Brazil. 11.III.2005. INPA 1645 \\
\hline 47 & & $-61.45684 /-1.906922$ & Cutiuaú Lake, PNJ, bacia do Jaú River, Amazonas State. 21.III.2003. \\
\hline 48 & & $-60.26722 /-3.033334$ & Cachoeira Stream, Tupé Lake, Rio Negro, Amazonas State, Brazil. 19.X.02. INPA 1567 1. Col. Previattelli, D. \\
\hline 49 & & $-64.66306 /-2.583716$ & Amanã Lake, Amazonas State, Brazil. 07.XI.1979. Col. Best, R. \\
\hline 50 & & $-62.85899 /-8.088754$ & Machado River, Calama, Amazonas State, Brazil. 18.XII.1993. \\
\hline 51 & & $-60.56569 /-2.759728$ & Maravilha Sream, Anavilhanas, Amazonas State, Brazil, 22.XI.1996. Col. Hardy, E. R. \\
\hline 52 & D. azureus & $-41.69085 /-22.2938$ & Cabiúnas Lake, Rio de Janeiro State, Brazil. Col. Marinho, P. Jan 2005; Jul 2007; Jan 2008; Sep 2009 \\
\hline
\end{tabular}


APPEndix. CONTINUED.

\begin{tabular}{|c|c|c|c|}
\hline & SPECIES & LONG./ LAT. & DESCRIPTION \\
\hline 53 & & $-41.4326 /-22.17663$ & Small pool near Macaé city, Rio de Janeiro State, Brazil, VIII. 2009. Col. Marinho, P. \\
\hline 54 & D. ohlei & $-61.68256 /-3.907406$ & Ananá Lake, Amazonas State, Brazil. 2009 Gasoduto Coari-Manaus Project. \\
\hline 55 & & $-62.34526 /-3.760222$ & Araçá Lake, Amazonas State, Brazil. 2009 Gasoduto Coari-Manaus Project. \\
\hline 56 & & $-55.93081 /-1.442938$ & Salgado Lake, Cabeceira do Boi, Pará State, Brazil. \\
\hline 57 & & $-58.31700 /-3.169877$ & Pucu Lake, Itacoatiara, Amazonas River, Amazonas State, Brazil. 09.VII.2005, 11h25. Col. Calixto, L.S.F. INPA 1589 \\
\hline 58 & & $-60.03099 /-3.211052$ & Janauari Lake, Amazonas State, Brazil, XI. 2009. \\
\hline 60 & N. amazonicus & $-62.99345 /-4.09650$ & $\begin{array}{l}\text { Mamiá Ria Lake, Coarí, Amazonas State, Brazil. Sample LRMA. VI. 2008. Col. Darwich, A. J. Gasoduto Coari- } \\
\text { Manaus Project }\end{array}$ \\
\hline 61 & & $-59.59328 /-3.137966$ & Paraná do Rei, Ilha do Careiro, Amazonas State, Brazil. 04.III.1987. Santos-Silva, E.N. \\
\hline 62 & & $-61.42639 /-3.354711$ & Maracá Islad, Uraricoera River, 135 km from Boa Vista Acre State. 1985. Col. Robertson, B. and Santos-Silva, E.N. \\
\hline 63 & N. anisitsi & $-51.40631 /-26.05919$ & $\begin{array}{l}\text { Foz do Areia Reservoir, Iguassu River, Upper Paraná River Basin, Paraná State, Brazil. II.2010. Col. Perbiche- } \\
\text { Neves, G. }\end{array}$ \\
\hline 64 & & $-51.64439 /-25.99828$ & Foz do Areia Reservoir, Iguassu River, Upper Paraná River, Paraná State, Brazil. II.2010. Col. Perbiche-Neves, G. \\
\hline 66 & & $-57.80080 /-30.77366$ & Salto Grande Reservoir, Lower Uruguay River, Salto Province, Uruguay. II.2010. Col. Perbiche-Neves, G. \\
\hline 67 & & $-57.93065 /-31.26980$ & Salto Grande Reservoir, Lower Uruguay River, Salto Province, Uruguay. II.2010. Col. Perbiche-Neves, G. \\
\hline 68 & & $-60.72481 /-32.73571$ & Lower Paraná River, Corrientes Province, Argentina. I.2010. Col. Perbiche-Neves, G. \\
\hline 69 & & $-58.43775 /-33.80992$ & Lower Uruguay River, Soriano Province, Uruguay. II.2010. Col. Perbiche-Neves, G. \\
\hline 70 & N. brandorffi & $-44.89430 /-3.791666$ & Açu Lake, Rio Mearim, Maranhão State, Brazil, 13.X.1983. Col. Darwich, A. J. \\
\hline 71 & N. carteri & $-60.72077 /-32.69155$ & Lower Paraná River, Santa Fé Province, Argentina. I.2010. Col. Perbiche-Neves, G. \\
\hline 72 & & $-59.63867 /-33.67196$ & Lower Paraná River, Buenos Aires Province, Argentina. I.2010. Col. Perbiche-Neves, G. \\
\hline 73 & N. cearensis & $-40.05324 /-13.50526$ & BR116, 36 Km from Jequié, Bahia, Brazil, 11.V.2000. Col. Santos-Silva, E. N. \\
\hline 74 & & $-39.00690 /-12.56599$ & Pedra do Cavalo Reservoir, Paraguaçu River, Bahia State, Brazil. V.2010. Col. Serafim Jr., M. \\
\hline 75 & & $-48.46541 /-22.53319$ & $\begin{array}{l}\text { Barra Bonita Reservoir, Tietê River, Upper Paraná River Basin, São Paulo State, Brazil. III.2010. Col. Perbiche- } \\
\text { Neves, G. }\end{array}$ \\
\hline 76 & & $-50.60245 /-20.96116$ & $\begin{array}{l}\text { Três Irmãos Reservoir, Tietê River, Upper Paraná River Basin, São Paulo State, Brazil. II.2010. Col. Perbiche- } \\
\text { Neves, G. }\end{array}$ \\
\hline 77 & & $-51.10782 /-20.68612$ & $\begin{array}{l}\text { Três Irmãos Reservoir, Tietê River, Upper Paraná River Basin, São Paulo State, Brazil. II.2010. Col. Perbiche- } \\
\text { Neves, G. }\end{array}$ \\
\hline 79 & & $-51.04018 /-20.18523$ & Ilha Solteira Reservoir, Upper Paraná River Basin, São Paulo State, Brazil River. II.2010. Col. Perbiche-Neves, G. \\
\hline 80 & & $-49.75692 /-19.92461$ & $\begin{array}{l}\text { Água Vermelha Reservoir, Grande River, Upper Paraná River Basin, Minas Gerais State, Brazil. II.2010. Col. } \\
\text { Perbiche-Neves, G. }\end{array}$ \\
\hline 81 & & $-50.50116 /-18.99462$ & $\begin{array}{l}\text { São Simão Reservoir, Parnaíba River, Upper Paraná River Basin, Minas Gerais State, Brazil. II.2010. Col. Perbiche- } \\
\text { Neves, G. }\end{array}$ \\
\hline 82 & & $-50.08045 /-18.67213$ & $\begin{array}{l}\text { São Simão Reservoir, Parnaíba River, Upper Paraná River Basin, Minas Gerais State, Brazil. II.2010. Col. Perbiche- } \\
\text { Neves, G. }\end{array}$ \\
\hline 83 & & $-47.73479 /-18.37112$ & $\begin{array}{l}\text { Emborcação Reservoir, Parnaíba River, Upper Paraná River Basin, Goiás State, Brazil. II.2010. Col. Perbiche- } \\
\text { Neves, G. }\end{array}$ \\
\hline 84 & & $-47.96788 /-18.48847$ & $\begin{array}{l}\text { Emborção Reservoir, Parnaíba River, Upper Paraná River Basin, Goiás State, Brazil. II.2010. Col. Perbiche-Neves, } \\
\text { G. }\end{array}$ \\
\hline 85 & N. conifer & $-48.52918 /-22.52729$ & $\begin{array}{l}\text { Barra Bonita Reservoir, Tietê River, Upper Paraná River Basin, São Paulo State, Brazil. III.2010. Col. Perbiche- } \\
\text { Neves, G. }\end{array}$ \\
\hline 86 & & $-48.35103 /-22.66645$ & $\begin{array}{l}\text { Barra Bonita Reservoir, Tiete River, Upper Paraná River Basin, São Paulo State, Brazil. III.2010. Col. Perbiche- } \\
\text { Neves, G. }\end{array}$ \\
\hline 87 & & $-48.70811 /-23.33245$ & $\begin{array}{l}\text { Jurumirim Reservoir, Paranápanema River, Upper Paraná River Basin, São Paulo State, Brazil. III.2010. Col. } \\
\text { Perbiche-Neves, G. }\end{array}$ \\
\hline 88 & & $-57.63847 /-18.97899$ & Upper Paraguay River, near Corumbá city, Brazil. II.2010. Col. Perbiche-Neves, G. \\
\hline 89 & & $-59.62521 /-33.68451$ & Lower Paraná River, Santa Fé Province, Argentina. I.2010. Col. Perbiche-Neves, G. \\
\hline 90 & & $-60.72314 /-32.72957$ & Lower Paraná River, Buenos Aires Province, Argentina. I.2010. Col. Perbiche-Neves, G. \\
\hline 91 & N. deitersi & $-49.66614 /-5.944468$ & LA Lake, Serra Leste, Carajás, Pará State, Brazil. INPA 1576 \\
\hline 92 & & $-49.64788 /-5.949981$ & S11A-C, Serra Leste, Carajás, Pará State, Brazil. INPA 1577 \\
\hline 93 & & $-50.20787 /-6.043042$ & Lagoa N3, Serra Norte, Carajás, Pará State, Brazil. INPA 1578 \\
\hline 94 & N. dentatus & $-56.50975 /-27.48885$ & Yaciretá Reservoir, Middle Paraná River, Argentina/Paraguay. I.2010. Col. Perbiche-Neves, G. \\
\hline 95 & & $-60.38903 /-31.64114$ & Lower Paraná River, Santa Fé Province, Argentina. I.2010. Col. Perbiche-Neves, G. \\
\hline 96 & & $-60.72277 /-32.73638$ & Lower Paraná River, Santa Fé Province, Argentina. I.2010. Col. Perbiche-Neves, G. \\
\hline 97 & N. henseni & $-51.52044 /-20.64725$ & Itapura, at the western extremity of São Paulo State, Brazil. Col. Santos-Silva, E. N. \\
\hline 98 & & $-56.63382 /-18.96578$ & Sample 1 - Pantanal da Nhecolândia. \\
\hline 99 & & $-56.51512 /-27.51612$ & Yaciretá Reservoir, Middle Paraná River, Argentina/Paraguay. I.2010. Col. Perbiche-Neves, G. \\
\hline
\end{tabular}


APPEndix. CONTINUED.

\begin{tabular}{|c|c|c|c|}
\hline & SPECIES & LONG./ LAT. & DESCRIPTION \\
\hline 102 & & $-53.48344 /-25.53062$ & $\begin{array}{l}\text { Salto Caxias Reservoir, Iguassu River, Upper Paraná River Basin, Paraná State, Brazil. I.2010. Col. Perbiche-Neves, } \\
\text { G. }\end{array}$ \\
\hline 103 & & $-54.55017 /-25.40832$ & Itaipu Reservoir, Upper Paraná River, Brazil/Paraguay. I.2010. Col. Perbiche-Neves, G. \\
\hline 104 & & $-54.32909 /-25.40832$ & Itaipu Reservoir, Upper Paraná River, Brazil/Paraguay. I.2010. Col. Perbiche-Neves, G. \\
\hline 105 & & $-52.85114 /-22.59898$ & $\begin{array}{l}\text { Rosana Reservoir, Paranápanema River, Upper Paraná River Basin, São Paulo State, Brazil. II.2010. Col. Perbiche- } \\
\text { Neves, G. }\end{array}$ \\
\hline 106 & & $-52.16070 /-22.61236$ & $\begin{array}{l}\text { Rosana Reservoir, Paranápanema River, Upper Paraná River Basin, São Paulo State, Brazil. II.2010. Col. Perbiche- } \\
\text { Neves, G. }\end{array}$ \\
\hline 107 & & $-49.22643 /-23.22217$ & $\begin{array}{l}\text { Jurumirim Reservoir, Paranápanema River, Upper Paraná River Basin, São Paulo State, Brazil. III.2010. Col. } \\
\text { Perbiche-Neves, G. }\end{array}$ \\
\hline 108 & & $-48.70537 /-23.32420$ & $\begin{array}{l}\text { Jurumirim Reservoir, Paranápanema River, Upper Paraná River Basin, São Paulo State, Brazil. III.2010. Col. } \\
\text { Perbiche-Neves, G. }\end{array}$ \\
\hline 109 & & $-48.34862 /-22.66829$ & Barra Bonita Reservoir, Tietê River, Upper Paraná River, São Paulo State, Brazil. III.2010. Col. Perbiche-Neves, G. \\
\hline 110 & & $-48.52830 /-22.52759$ & Barra Bonita Reservoir, Tietê River, Upper Paraná River, São Paulo State, Brazil. II.2010. Col. Perbiche-Neves, G. \\
\hline 111 & & $-50.60317 /-20.96259$ & Três Irmãos Reservoir, Tietê River, Upper Paraná River, São Paulo State, Brazil. II.2010. Col. Perbiche-Neves, G. \\
\hline 112 & & $-51.11977 /-20.68106$ & Três Irmãos Reservoir, Tietê River, Upper Paraná River, São Paulo State, Brazil. II.2010. Col. Perbiche-Neves, G. \\
\hline 113 & & $-51.34474 /-20.36701$ & Ilha Solteira Reservoir, Upper Paraná River, São Paulo State, Brazil. II.2010. Col. Perbiche-Neves, G. \\
\hline 114 & & $-51.04027 /-20.18015$ & Ilha Solteira Reservoir, Upper Paraná River, São Paulo State, Brazil. II.2010. Col. Perbiche-Neves, G. \\
\hline 115 & & $-49.74668 /-19.92490$ & $\begin{array}{l}\text { Água Vermelha Reservoir, Grande River, Upper Paraná River, Minas Gerais State, Brazil. II.2010. Col. Perbiche- } \\
\text { Neves, G. }\end{array}$ \\
\hline 116 & & $-50.32115 /-19.85929$ & $\begin{array}{l}\text { Água Vermelha Reservoir, Grande River, Upper Paraná River, Minas Gerais State, Brazil. II.2010. Col. Perbiche- } \\
\text { Neves, G. }\end{array}$ \\
\hline 117 & & $-50.50272 /-18.99064$ & $\begin{array}{l}\text { São Simão Reservoir, Parnaíba River, Upper Paraná River Basin, Minas Gerais State, Brazil. II.2010. Col. Perbiche- } \\
\text { Neves, G. }\end{array}$ \\
\hline 118 & & $-50.07464 /-18.66676$ & $\begin{array}{l}\text { São Simão Reservoir, Parnaíba River, Upper Paraná River Basin, Minas Gerais State, Brazil. II.2010. Col. Perbiche- } \\
\text { Neves, G. }\end{array}$ \\
\hline 119 & & $-47.73389 /-18.37237$ & $\begin{array}{l}\text { Emborcação Reservoir, Parnaíba River, Upper Paraná River Basin, Goiás State, Brazil. II.2010. Col. Perbiche- } \\
\text { Neves, G. }\end{array}$ \\
\hline 120 & & $-45.96940 /-20.76144$ & $\begin{array}{l}\text { Furnas Reservoir, Grande River, Upper Paraná River Basin, Minas Gerais State, Brazil. II.2010. Col. Perbiche- } \\
\text { Neves, G. }\end{array}$ \\
\hline 121 & & $-46.30290 /-20.66304$ & $\begin{array}{l}\text { Furnas Reservoir, Grande River, Upper Paraná River Basin, Minas Gerais State, Brazil. II.2010. Col. Perbiche- } \\
\text { Neves, G. }\end{array}$ \\
\hline 122 & & $-45.51951 /-20.97668$ & $\begin{array}{l}\text { Furnas Reservoir, Grande River, Upper Paraná River Basin, Minas Gerais State, Brazil. II.2010. Col. Perbiche- } \\
\text { Neves, G. }\end{array}$ \\
\hline 123 & N. iheringi & $-52.99432 /-25.55716$ & Salto Osório Reservoir, Iguassu River, Upper Paraná River Basin, Paraná State, Brazil. \\
\hline 124 & & $-47.73434 /-18.37249$ & $\begin{array}{l}\text { Emborcação Reservoir, Parnaíba River, Upper Paraná River Basin, Goiás State, Brazil. II.2010. Col. Perbiche- } \\
\text { Neves, G. }\end{array}$ \\
\hline 125 & & $-47.96528 /-18.48853$ & $\begin{array}{l}\text { Emborcação Reservoir, Parnaíba River, Upper Paraná River Basin, Goiás State, Brazil. II.2010. Col. Perbiche- } \\
\text { Neves, G. }\end{array}$ \\
\hline 126 & & $-50.49742 /-19.00124$ & $\begin{array}{l}\text { São Simão Reservoir, Parnaíba River, Upper Paraná River Basin, Minas Gerais State, Brazil. II.2010. Col. Perbiche- } \\
\text { Neves, G. }\end{array}$ \\
\hline 127 & & $-51.03645 /-20.17496$ & Ilha Solteira Reservoir, Upper Paraná River, São Paulo State, Brazil. I.2010. Col. Perbiche-Neves, G. \\
\hline 128 & & $-51.35246 /-20.37141$ & Ilha Solteira Reservoir, Upper Paraná River, São Paulo State, Brazil. I.2010. Col. Perbiche-Neves, G. \\
\hline 129 & & $-51.11784 /-20.68105$ & Três Irmãos Reservoir, Tietê River, Upper Paraná River, São Paulo State, Brazil. II.2010. Col. Perbiche-Neves, G. \\
\hline 130 & & $-50.60499 /-20.95918$ & Tres Irmãos Reservoir, Tietê River, Upper Paraná River, São Paulo State, Brazil. II.2010. Col. Perbiche-Neves, G. \\
\hline 131 & & $-48.53048 /-22.52529$ & Barra Bonita Reservoir, Tietê River, Upper Paraná River, São Paulo State, Brazil. VII.2009. Col. Zaganini, R. \\
\hline 132 & & $-48.35065 /-22.66826$ & Barra Bonita Reservoir, Tietê River, Upper Paraná River, São Paulo State, Brazil. III.2010. Col. Perbiche-Neves, G. \\
\hline 133 & & $-49.68233 /-19.93446$ & Barra Bonita Reservoir, Tietê River, Upper Paraná River, São Paulo State, Brazil. III.2010. Col. Perbiche-Neves, G. \\
\hline 134 & & $-46.30302 /-20.66229$ & $\begin{array}{l}\text { Furnas Reservoir, Grande River, Upper Paraná River Basin, Minas Gerais State, Brazil. II.2010. Col. Perbiche- } \\
\text { Neves, G. }\end{array}$ \\
\hline 135 & & $-45.52056 /-20.97544$ & $\begin{array}{l}\text { Furnas Reservoir, Grande River, Upper Paraná River Basin, Minas Gerais State, Brazil. II.2010. Col. Perbiche- } \\
\text { Neves, G. }\end{array}$ \\
\hline 136 & & $-52.16122 /-22.59438$ & $\begin{array}{l}\text { Rosana Reservoir, Paranápanema River, Upper Paraná River Basin, São Paulo State, Brazil. II.2010. Col. Perbiche- } \\
\text { Neves, G. }\end{array}$ \\
\hline 137 & & $-54.32958 /-24.49047$ & Itaipu Reservoir, Upper Paraná River, Brazil/Paraguay. I.2010. Col. Perbiche-Neves, G. \\
\hline 138 & N. isabelae & $-56.27216 /-27.42376$ & Yaciretá Reservoir, Middle Paraná River, Argentina/Paraguay. I.2010. Col. Perbiche-Neves, G. \\
\hline 139 & & $-56.51464 /-27.50691$ & Yaciretá Reservoir, Middle Paraná River, Argentina/Paraguay. I.2010. Col. Perbiche-Neves, G. \\
\hline 140 & & $-58.31754 /-26.85113$ & Lower Paraguay River, Formosa Province, Argentina. I.2010. Col. Perbiche-Neves, G. \\
\hline 141 & & $-59.05641 /-28.50193$ & Middle Paraná River, Santa Fé Province, Argentina. I.2010. Col. Perbiche-Neves, G. \\
\hline 142 & & $-59.56367 /-30.01467$ & Middle Paraná River, Santa Fé Province, Argentina. I.2010. Col. Perbiche-Neves, G. \\
\hline 143 & N. incompositus & $-51.36072 /-26.07726$ & Foz do Areia Reservoir, Iguassu River, Upper Paraná River, Paraná State, Brazil. I.2010. Col. Perbiche-Neves, G. \\
\hline 144 & & $-51.63839 /-25.99930$ & Foz do Areia Reservoir, Iguassu River, Upper Paraná River, Paraná State, Brazil. I.2010. Col. Perbiche-Neves, G. \\
\hline 145 & & $-53.31013 /-25.51059$ & $\begin{array}{l}\text { Salto Caxias Reservoir, Iguassu River, Upper Paraná River Basin, Paraná State, Brazil. I.2010. Col. Perbiche-Neves, } \\
\text { G. }\end{array}$ \\
\hline 146 & & $-53.48478 /-25.53116$ & $\begin{array}{l}\text { Salto Caxias Reservoir, Iguassu River, Upper Paraná River Basin, Paraná State, Brazil. I.2010. Col. Perbiche-Neves, } \\
\text { G. }\end{array}$ \\
\hline
\end{tabular}


APPEndix. CONTINUED.

\begin{tabular}{|c|c|c|c|}
\hline & SPECIES & LONG./ LAT. & DESCRIPTION \\
\hline 147 & & $-51.62270 /-27.51293$ & Machadinho Reservoir, Upper Uruguay River, Rio Grande do Sul State, Brazil. II.2010. Col. Perbiche-Neves, G. \\
\hline 148 & & $-51.80010 /-27.49273$ & Machadinho Reservoir, Upper Uruguay River, Rio Grande do Sul State, Brazil. II.2010. Col. Perbiche-Neves, G. \\
\hline 149 & & $-54.19319 /-27.29038$ & Middle Uruguay River, Rio Grande do Sul State, Brazil. I.2010. Col. Perbiche-Neves, G. \\
\hline 150 & & $-56.24612 /-27.41091$ & Yaciretá Reservoir, Middle Paraná River, Argentina/Paraguay. I.2010. Col. Perbiche-Neves, G. \\
\hline 151 & & $-56.02199 /-28.54757$ & Middle Uruguay River, Rio Grande do Sul State, Brazil. I.2010. Col. Perbiche-Neves, G. \\
\hline 152 & & $-57.80210 /-30.77734$ & Salto Grande Reservoir, Lower Uruguay River, Salto Province, Uruguay \\
\hline 153 & & $-57.93387 /-31.26771$ & Salto Grande Reservoir, Lower Uruguay River, Salto Province, Uruguay. I.2010. Col. Perbiche-Neves, G. \\
\hline 154 & & $-60.72313 /-32.73117$ & Lower Paraná River, Santa Fe Province, Argentina. I.2010. Col. Perbiche-Neves, G. \\
\hline 155 & & $-59.62702 /-33.68263$ & Lower Paraná River, Buenos Aires Province, Argentina. I.2010. Col. Perbiche-Neves, G. \\
\hline 156 & & $-58.44402 /-33.80574$ & Lower Uruguay River, Colonia Province, Uruguay. I.2010. Col. Perbiche-Neves, G. \\
\hline 157 & & $-58.45310 /-33.94177$ & Lower Paraná River, Buenos Aires Province, Argentina. I.2010. Col. Perbiche-Neves, G. \\
\hline 158 & & $-58.00850 /-34.46784$ & Río de la Plata River, Uruguay. I.2010. Col. Perbiche-Neves, G. \\
\hline 159 & N. coniferoides & $-63.52083 /-4.15875$ & $\begin{array}{l}\text { Lago Ria Urucu, Coarí, Amazonas, Brazil, sample LURC. VI. 2008. col. Darwich, A. J. Gasoduto Coari-Manaus } \\
\text { Project }\end{array}$ \\
\hline 160 & & $-57.63864 /-18.97950$ & Upper Paraguay River, near Corumbá city, Mato Grosso do Sul State, Brazil. II.2010. Col. Perbiche-Neves, G. \\
\hline 161 & & $-57.88486 /-21.68349$ & Middle Paraguay River, Mato Grosso do Sul State, Brazil. II.2010. Col. Perbiche-Neves, G. \\
\hline 162 & & $-58.31869 /-26.85168$ & Lower Paraguay River, Formosa Province, Argentina. I.2010. Col. Perbiche-Neves, G. \\
\hline 163 & & $-56.47729 /-27.52756$ & Yaciretá Reservoir, Middle Paraná River, Argentina/Paraguay. I.2010. Col. Perbiche-Neves, G. \\
\hline 164 & & $-59.56284 /-30.01603$ & Middle Paraná River, Santa Fé Province, Argentina. I.2010. Col. Perbiche-Neves, G. \\
\hline 165 & & $-60.39547 /-31.64626$ & Middle Paraná River, Santa Fé Province, Argentina. I.2010. Col. Perbiche-Neves, G. \\
\hline 166 & & $-59.62519 /-33.68406$ & Lower Paraná River, Buenos Aires Province, Argentina. I.2010. Col. Perbiche-Neves, G. \\
\hline 167 & & $-58.46124 /-33.94154$ & Lower Paraná River, Buenos Aires Province, Argentina. I.2010. Col. Perbiche-Neves, G. \\
\hline 168 & N. paraensis & $-41.69085 /-22.2938$ & Cabiúnas Lake, Rio de Janeiro, Brazil, Col. Marinho, P. Jan 2005; Jul 2007; Jan 2008; Sep 2009 \\
\hline 169 & & $-50.14275 /-6.050180$ & N8 Lake, Serra Norte, Carajás, Pará, Brazil, INPA 1571. \\
\hline 170 & & $-50.35381 /-6.398261$ & S11D-A Lake, Serra Sul, Carajás, Pará, Brazil. INPA 1575 \\
\hline 171 & & $-54.66137 /-2.461792$ & "Stations” south of Santarém, Pará, Brazil. \\
\hline 172 & & $-54.30158 /-2.818124$ & Curuá-Una Reservoir, Pará, Brazil. I.2010. Col. Perbiche-Neves, G. \\
\hline 173 & N. santafesinus & $-58.31899 /-26.85668$ & Lower Paraguay River, Formosa Province, Argentina. I.2010. Col. Perbiche-Neves, G. \\
\hline 174 & & $-59.56324 /-30.01805$ & Middle Paraná River, Santa Fé Province, Argentina. I.2010. Col. Perbiche-Neves, G. \\
\hline 175 & & $-60.39025 /-31.64011$ & Middle Paraná River, Santa Fé Province, Argentina. I.2010. Col. Perbiche-Neves, G. \\
\hline 176 & & $-59.62464 /-33.68500$ & Lower Paraná River, Buenos Aires Province, Argentina. I.2010. Col. Perbiche-Neves, G. \\
\hline 177 & N. simillimus & $-63.37296 /-4.200152$ & $\begin{array}{l}\text { Coari Ria Lake, Coarí, Amazonas, Brazil, sample LRCO. VI. 2008. Col. Darwich, A. J., Gasoduto Coari-Manaus } \\
\text { Project }\end{array}$ \\
\hline 178 & & $-63.56004 /-4.100075$ & $\begin{array}{l}\text { Aruã Ria Lake, Coarí, Amazonas, Brazil, sample LRAR. VI. 2008. Col. Darwich, A. J., Gasoduto Coari-Manaus } \\
\text { Project }\end{array}$ \\
\hline 179 & & $-63.52083 /-4.15875$ & $\begin{array}{l}\text { Urucu Ria Lake, Coarí, Amazonas, Brazil, sample LURC. VI. } 2008 \text { Col. Darwich, A. J., Gasoduto Coari-Manaus } \\
\text { Project }\end{array}$ \\
\hline 180 & & $-61.58808 /-3.758933$ & Aruã Lake, Amazonas, Brazil, 28.IX.2004. Col. Darwich. INPA 1613 \\
\hline 181 & N. spiniger & $-58.27982 /-34.38410$ & Río de la Plata River, Uruguay. II.2010. Col. Perbiche-Neves, G. \\
\hline 182 & & $-59.61631 /-33.68810$ & Middle Paraná River, Corrientes Province, Argentina. I.2010. Col. Perbiche-Neves, G. \\
\hline 183 & & $-60.72405 /-32.73164$ & Lower Paraná River, Santa Fé Province, Argentina. I.2010. Col. Perbiche-Neves, G. \\
\hline 184 & & $-57.92618 /-31.26344$ & Salto Grande Reservoir, Lower Uruguay River, Salto Province, Uruguay. I.2010. Col. Perbiche-Neves, G. \\
\hline 185 & & $-57.80017 /-30.77638$ & Salto Grande Reservoir, Lower Uruguay River, Salto Province, Uruguay. I.2010. Col. Perbiche-Neves, G. \\
\hline 186 & & $-59.05493 /-28.49829$ & Lower Paraná River, Buenos Aires Province. I.2010. Col. Perbiche-Neves, G. \\
\hline 187 & & $-51.62551 /-27.51755$ & Machadinho Reservoir, Upper Uruguay River, Rio Grande do Sul State, Brazil. II.2010. Col. Perbiche-Neves, G. \\
\hline 188 & & $-51.79187 /-27.48934$ & Machadinho Reservoir, Upper Uruguay River, Rio Grande do Sul State, Brazil. II.2010. Col. Perbiche-Neves, G. \\
\hline 189 & & $-51.40758 /-26.05884$ & Foz do Areia Reservoir, Iguassu River, Upper Paraná River, Paraná State, Brazil. II.2010. Col. Perbiche-Neves, G. \\
\hline 190 & & $-51.64355 /-25.99868$ & Foz do Areia Reservoir, Iguassu River, Upper Paraná River, Paraná State, Brazil. II.2010. Col. Perbiche-Neves, G. \\
\hline 191 & N. spinuliferus & $-51.88135 /-25.63821$ & Santa Clara Reservoir, Jordão River, Iguassu River Basin, Paraná State, Brazil. \\
\hline 192 & & $-51.78824 /-27.48825$ & Machadinho Reservoir, Upper Uruguay River, Rio Grande do Sul State, Brazil. I.2010. Col. Perbiche-Neves, G. \\
\hline 193 & & $-57.88261 /-21.68987$ & Upper Paraguay River, Mato Grosso do Sul State, Brazil, II.2010. Col. Perbiche-Neves, G. \\
\hline 194 & & $-57.64644 /-18.98176$ & Middle Paraguay River, Mato Grosso do Sul State, Brazil, II.2010. Col. Perbiche-Neves, G. \\
\hline 195 & & $-45.52293 /-20.97422$ & $\begin{array}{l}\text { Furnas Reservoir, Grande River, Upper Paraná River Basin, Minas Gerais State, Brazil. II.2010. Col. Perbiche- } \\
\text { Neves, G. }\end{array}$ \\
\hline 196 & N. jatobensis & $-3.214668 /-52.19127$ & Arapujá Island, Xingú River, 21.IX.1995. Col. Zuanon, J. \\
\hline 197 & O. paulistanus & $-45.83250 /-23.64382$ & Salesópolis, Estação Biológica Boracéia, Rio Claro, Pilões, São Paulo, Brazil. 03.VII.1992. \\
\hline 198 & R. calamensis & $-54.94804 /-2.494239$ & $\begin{array}{l}\text { Verde Lake, Alter-do-Chão, Rio Tapajós, Santarém, Pará, Brazil. 13.XI.2006. Col. Calixto, L.S.F. \& Pimpão, D.M. } \\
\text { INPA } 1643\end{array}$ \\
\hline 199 & & $-60.19191 /-6.013638$ & Mucutaia Lake, Rio Aripuanã, Novo Aripuanã, Amazonas, Brazil. 03.XI.2006. Col. Calixto, L. D. F. \\
\hline 200 & R. calatus & $-60.57002 /-3.308642$ & Calado Lake, Solimões, Manacapuru, Amazonas, Brazil. INPA 1569. 17.XII.1983. \\
\hline 201 & R. insolitus & $-62.74785 /-8.283832$ & $\begin{array}{l}\text { Paracuúba Lake, Cururú Lake, and Curumim River, Machado/Ji-Paraná and Igarapé do Chico Paiva, all near } \\
\text { Calama, Rondônia, Brazil. }\end{array}$ \\
\hline
\end{tabular}


APpendix. Continued.

\begin{tabular}{|c|c|c|c|}
\hline & SPECIES & LONG./ LAT. & DESCRIPTION \\
\hline 202 & & $-62.87662 /-8.038766$ & Lake near Calama and Rio Machado/Ji-Paraná, Rondônia, Brazil. \\
\hline 203 & R. retroflexus & $-62.99345 /-4.09650$ & $\begin{array}{l}\text { Mamiá Ria Lake, Coarí, Amazonas, Brazil, sample LRMA. VI. 2008. col. Darwich, A. J., Gasoduto Coari-Manaus } \\
\text { Project }\end{array}$ \\
\hline 204 & & $-63.52083 /-4.15875$ & $\begin{array}{l}\text { Urucu Ria Lake, Coarí, Amazonas, Brazil, sample LURC. VI. 2008. col. Darwich, A. J., Gasoduto Coari-Manaus } \\
\text { Project }\end{array}$ \\
\hline 205 & & $-63.37296 /-4.200152$ & $\begin{array}{l}\text { Coari Ria Lake, Coarí, Amazonas, Brazil, sample LRCO. VI. 2008. col. Darwich, A. J., Gasoduto Coari-Manaus } \\
\text { Project }\end{array}$ \\
\hline 206 & & $-63.08419 /-4.273495$ & Açu Lake, Mearim River, Maranhão State, Brazil, 13.X.1983. col. Darwich, A. J. \\
\hline 207 & & $-61.69771 /-3.836881$ & Mamiá Lake, Solimões River, Amazonas, Brazil, 02.VI.2006. INPA 1630 \\
\hline 208 & & $-61.47444 /-1.586408$ & Jauaperi River, Amazonas, Brazil, 11.III.2005. INPA 1645 \\
\hline
\end{tabular}

